\title{
HAS IMPLEMENTING AN ECOLABEL INCREASED SUSTAINABLE TOURISM IN BARCELONA?
}

\author{
Rocío Arenado Rodríguez \\ Ana García López. \\ José L. Jiménez Caballero \\ Universidad de Sevilla
}

\begin{abstract}
The aim of this study is to find out if by implementing an ecolabel in destinations, applying an SDM model, tourism sustainability increases. In order to this, three measures have been put into practice in Barcelona: (1) a focus group interview to key stakeholders (DMOs) see their implication with the certification project; (2) the implementations of two different actions relevant for the study: (a) to confront and pair up the certification body's set of criteria with the Global Sustainable Tourism Council (GSTC) ones, (b) check if the certification adapts to Font's study about ecolabels; and finally, (3) a discussion to find out if the media and local citizens felt in a city touristic ally sustainable. The findings show that Barcelona tourism board and other stakeholders were concerned about tourism sustainability. Besides, ecolabel can be believed to be trustworthy and reliable by adapting it to Font's study (2001) and by confronting it with GSTC destination criteria. However, local population seems not to be satisfied at all with how the city is getting so many tourism. They seems not to understand labels, but they understand the negative impacts from tourism in their way of life. The limitation to this study is that just the Barcelona case is analyzed. The contribution is that it is actually putting into practice well known concepts that have usually been studied in theoretical ways.
\end{abstract}

Keywords: sustainable tourism, sustainable indicators, Barcelona, ecolabel, strategic plan, local population, tourism stakeholders.

Recibido: 30 de marzo de 2017

Devuelto para su revisión: 1 de junio de 2017

Aceptado: 2 de septiembre de 2017

Facultad de Turismo y Finanzas. Universidad de Sevilla. Avda. San Francisco Javier, s/n. 41018 SEVILLA (España).E-mail: rocioarenado@gmail.com, angar@us.es, jjimenez@us.es 


\section{¿Puede una eco etiqueta incrementar la sostenibilidad turística en Barcelona?}

\section{RESUMEN}

El objetivo principal de este estudio es detectar si la implementación de una eco etiqueta en destinos turísticos con un modelo SDM, incrementa su sostenibilidad. Para dicha investigación, se han puesto en práctica tres medidas en Barcelona: (1) entrevistas con agentes locales clave (DMOs), para comprobar su aceptación e implicación en el proyecto de certificación; (2) la puesta en práctica de dos acciones relevantes para el estudio: (a) contrastar los criterios de la eco etiqueta objeto de estudio con los criterios del GSTC (2016), (b) comprobar si la eco etiqueta se adecua al estudio de Font (2001) sobre las mismas. Por último, como tercera medida (3), se plantea una discusión para conocer si los medios de comunicación y la población local perciben la ciudad como turísticamente sostenible. Los resultados establecen que tanto Barcelona Tourism Board como los agentes claves muestran preocupación, interés y compromiso frente a la sostenibilidad turística. Y respecto a la ecoetiqueta, puede comprobarse que es fiable, pues se adapta a las exigencias tanto del modelo de Font (2001) como a los criterios del GSTC. Sin embargo, la población local muestra una clara insatisfacción y malestar con el volumen de turistas que visita a la ciudad. Esta parece no entender de etiquetas, pero sí de impactos negativos del turismo en sus vidas. La principal limitación del estudio es que solo ha sido analizado el caso de Barcelona. Mientras que su contribución más interesante es la puesta en práctica de conceptos ampliamente aceptados, pero que por lo general se estudian más de forma teórica que sobre los destinos turísticos.

Palabras clave: turismo sostenible, Barcelona, eco etiqueta, plan estratégico, población local, agentes turísticos.

\section{INTRODUCTION}

In the existing literature the same phenomenon is often named in different ways, trying to mean the same: sustainable tourism, sustainable development through tourism, principles of sustainable development in tourism, tourism development in terms of sustainable tourism, etc. Scholars, governments, NGOs (Non-Governmental Organizations), scientists, researchers and participants in tourism are becoming increasingly concerned with this topic, due to the fact that sustainable tourism is regarded as the most desirable form of tourism development in particular areas, especially those which preserve the most natural and cultural authentic values (Butowski, 2010). It can certainly be seen that there has been a constant increase of environmental concern among the general public, making the environment one of the key tools to gain competitive advantage (Font, 2001). Moreover, "the tourism industry can play a key role in providing environmental information and raising awareness among tourists of the environmental consequences of their actions" (Malviya, 2005: 94).

Traditionally, the aim of most destination management models was focused on how tourism development would provide opportunities for the effective management of environmentally sensitive areas. However, throughout the years, the focus has shifted towards the part that tourism can play in reducing environmental pollution and resource consump- 
tion (UNEP, 2002). This has led many DMOs (Destination Management Organizations) to apply SDM (Sustainable Destination Management) models for sustainability assessment by using different plans, policy instruments and other tools, in order to stimulate awareness and make an impact on reduction (Schianetz et al., 2007).

Planning the tourism industry is crucial for a destination, especially because its effects are substantial and potentially long-standing (Michael, 1999). If a destination chooses to achieve sustainable tourism development, the actions by its stakeholders must be consistent, by implementing community-based approach to tourism (which involves the locals in decision-making) (Hall, 2005). Moreover, the importance of co-ordination (e.g. networks and partnerships) increases the competitiveness and sustainability of touristic destinations (Antón et al, 2011; Bramwell \& Lane, 2000; Lazzeretti \& Petrillo, 2006; Pavlovich, K. 2003; Saxena, 2005). Therefore, having a DMO applying a destination management model (with a clear strategy) is a must for any destination.

According to the different tools used in SDM models, ecolabels are the ones with the broadest scope and one of the most promising voluntary initiatives that lead to improvement of the destinations' environmental and sustainable performance (Ayuso, 2007; UNEP, 1998). However, it has to be highlighted that ecolabels are controversial topics in tourism because some authors claim that they perform more as a market mechanism to influence consumers'choice than as sustainability tools. Naturefriends International (2012), however, asserts that "The greater extent to which a label takes into account the ecological, social and cultural concerns of the host population, the more it can contribute to sustainable development".

The foreword of these two opposite ideas aim to set the introduction of this study, which is to discover if by implementing an ecolabel in destinations applying an SDM model, sustainability increases. Barcelona was the first city in the world to obtain a destination certification, so the analysis of this topic is important due to the fact that nowadays it is accepted that the desirable state of tourism is the sustainable one. Do certifications really help towards being more sustainable? Is Barcelona more sustainable now, after getting the certification?

In order to answer these questions, the paper includes some literature review about ecolabels, an in-depth explanation about Barcelona and the ecolabel that has been implemented, as well as an extensive methodology that challenges this ecolabel. The research finishes with a conclusion summing up the study and presenting the findings.

\section{LITERATURE REVIEW}

There has been many studies concerning sustainable tourism, especially in the $90 \mathrm{~s}$ (Archer, 1996; Bramwell \& Lane, 1993; Green, 1995; Liu \& Jones, 1996; McIntyre et al, 1995; Wahab \& Pigram, 1998). According to Buckley (2012), there has been over 5000 published papers in this field of study. This topic has traditionally arose interest (Ruhanen et al, 2015), as well as critics (Liu, 2003). Afterwards, studies including ways to measure this sustainability through tools (indicators, model, index) became also popular (Castellani \& Salas, 2010; Cernat \& Gourdon, 2012; Fernández \& Rivero, 2009; Ko, 2005; Miller, 2001; Pulido \& Sánchez, 2009; Schianetz \& Kavanagh, 2008; Singh et al, 
2009). Organizations as GSTC and the European Tourism Indicators System (ETIS) also contributed to the development of this field of study (Fernández et al, 2017).

In the context of sustainable tourism development, Ecolabels were also developed mainly in the 90s and may be seen as both an environmental management and a marketing tool as they help to reduce negative impacts and increase competitive advantage (Buckley, 2001, 2002; Fairweather, Maslin, \& Simmons, 2005; Font, 2002; Hamele, 2001, Honey \& Stewart, 2002).

The large number and diversity of ecolabels makes it difficult to create a single definition for all of them (Kozak \& Nield, 2004); nevertheless, UNEP (United Nations Environmental Program) suggested the following 'a seal or label which assists the market to identify products or services as being less harmful to the environment than similar products or services with the same function' (UNEP, 1998:47). Buckley (2002) also indicates that a label is a basic description of something, associated with it in some way so that a potential purchaser can obtain information from it rather than the object itself. In its broadest sense, an ecolabel is simply one whose content refers mainly to the environment. Bearing these tasks in mind, it is understood that when implementing an ecolabel, not just the consumer's choice is taken into account, but, its sustainable aspect.

Ecolabels must be considered inputs in the sense of environmental management effort (measures taken) and output in the sense of impact produced (benefits for the environment) (Buckley, 2002). They usually encourage businesses to raise their standards of environmental performance and allow destinations to demonstrate their environmental credentials to customers (WTO, 2007). However, even though ecolabels in the tourism services has been extensively studied, there is no agreement whether or not eco certification increases tourist demand for a product among the general tourist population.

\subsection{Technical Features of ecolabels}

There is a considerable misunderstanding between the terms ecolabel and certification, because they usually have the same structure and both recognize the achievement of the criteria with a label or logo. Likewise, it is more and more common for both to include the three sustainable pillars (environmental, economic and socio-cultural) in their criteria. However, there are differences among them: the origins of certifications are in the manufacturing industry, and later in time, ecolabels were introduced as a formalized method, more focused on environmental efficiency. In 1985 the first milestones for environmental certification were settled (Font, 2002), and somehow, a misunderstanding arose: confusion between certification as a process and certification as an end. As previously stated, a certification company is the one that controls and ensures the fulfilment of the standards (certified by...) whereas an ecolabel refers to the compromise of guarantee. Nonetheless, this differentiation is not always very clear, because nowadays there are not many existing ecolabels without the backup of a certification body; therefore, it is used indistinctly. For the purpose of this paper, and better readability, the terms certification and ecolabels will be used interchangeably (especially because the ecolabels being studied - Biosphere World Class Destination - and their certification scheme - STR (Responsible Tourism System) are part of the same awarding body - ITR (Responsible Tourism Institute). 
Ecolabels can be applied to product, services and destinations; yet, this study will always refer to the destination ones, as is the case of this study.

Ecolabels can still be very different in terms of scope, popularity, quality, credibility, etc. Yet, the aim of ecolabels is usually the same, which is to improve the environmental performance. In figure 1, Font (2001) shows the different players that need to be involved in an ecolabel in order to be trustful.

\section{Figure 1}

\section{THE PLAYERS IN TOURISM ECOLABELS}

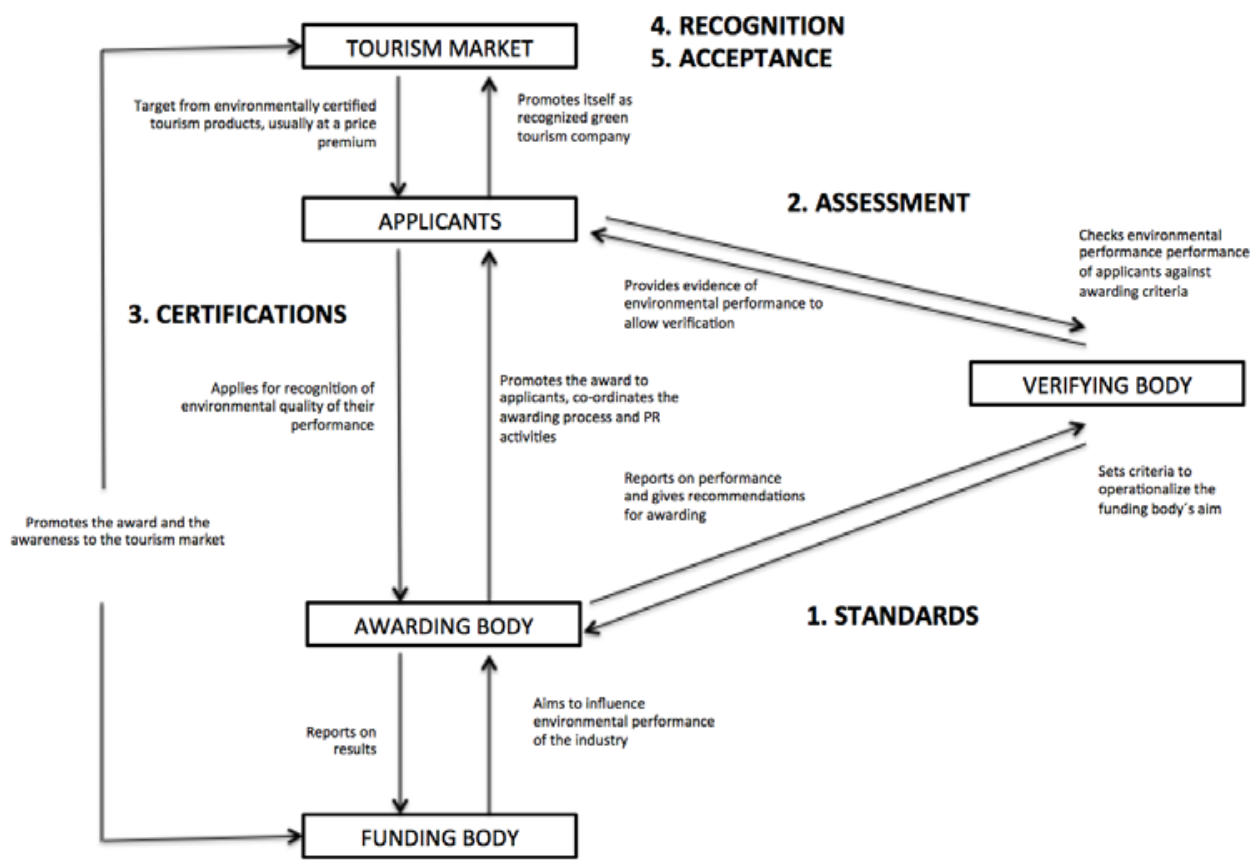

Source: Font (2001).

In this chart, the different concepts mean the following:

1. Standards: A document approved by a recognised body that provides for common and repeated use of a prescribed set of rules, conditions or requirements.

2. Assessment: Process of examining, measuring, testing or otherwise determining conformance with requirements specified in an applicable standard.

3. Certification: The procedure by which a third party (i.e. the awarding body) gives written assurance to the consumer (and the industry in general) that a product, process, service, or management system conforms to specified requirements (Toth, 2000). 
4. Recognition and acceptance: The basic purpose of such systems is to lead to recognition and acceptance by the industry as a strong voluntary standard, met by a crucial mass of players, and by the market as a quality symbol and a meaningful difference that influence purchasing behaviour (Font, 2002).

The previous chart can be summarized by stating that for an ecolabel to be meaningful and trustful, this must be part of an ecolabel scheme accompanied by the use of certain indicators-criteria-, which are instruments to measure impacts and set procedures. These criteria are made up of standards and administered by a reputable organization. Without this backup, the ecolabel could end up being meaningless (Buckley, 2001; Diamantis \& Westlake, 2001). Furthermore, the certification criteria should be disclosed and published in order to guarantee transparency (Naturefriends International, 2012).

\section{CASE STUDY: BARCELONA}

Before introducing the case study, it is important to consider the value and importance of tourism in Barcelona. It is a city located in the Catalonian region in the north east part of Spain. It is the third city most visited in Europe after London and Paris and the 12th in the World (Hedrick-Won \& Choong, 2016) and does not need much description as it is very well known. Moreover, over the last decades Barcelona has become one of the most successful models of urban development and place branding. The city complements its offer with many sports events, as well as finely developed shopping possibilities. This destination will only be presented in figures:

\section{Table 1}

\section{BARCELONA IN FIGURES}

\begin{tabular}{|l|c|c|}
\hline \multicolumn{1}{|c|}{ Criteria } & Data: 2015 & Evolution from 2011 \\
\hline Inhabitants in Barcelona city & 1.604 .555 & $-0.7 \%$ \\
\hline Inhabitants in Barcelona region & 5.523 .922 & $-0.9 \%$ \\
\hline Visitors & 8.303 .649 & $+112 \%$ \\
\hline Overnight stays & 17.656 .329 & $+114 \%$ \\
\hline Airport passengers & 39.711 .276 & $+115 \%$ \\
\hline AVE (high speed train) passengers & 3.717 .900 & $+143 \%$ \\
\hline Travellers coming on a cruise & 2.364 .292 & $+1 \%$ \\
\hline Beds offered & 7.2946 & $+114 \%$ \\
\hline Business meetings a year & 2.268 & $-0,6 \%$ \\
\hline
\end{tabular}

Source: Instituto de Estadística de Cataluña (2015), Departament d'Estadística. Ajuntament de Barcelona (2015), INE (2016), Barcelona Convention Bureau (2016), Barcelona Turisme (2010b; 2016).

As Barcelona has been increasingly receiving more tourists throughout the years, they are constantly trying to improve what they offer. To do so, in 2010, Barcelona City Council 
together with the DMO, created the Strategic Plan for the city together with 8.000 people for different sectors. This Plan was focused on economic, social and environmental sustainability as its main principles. The Plan assumed these principles and believed that tourism is not a closed, independent economic sector, but a transversal reality. Moreover, the aim of the Plan was to maintain Barcelona's international leadership as a prescriptor and innovative destination, which considering the tourists statistics seen above, seems fulfilled.

This plan revealed the importance that the city gave to sustainability as it can be appreciated on the core objectives and focuses (Barcelona Turisme, 2010a):

Table 2

\section{BARCELONA TOURISM STRATEGIC PLAN 2010-2015}

\section{Core Objectives for 2015}

Fostering improvements to tourist activity in Barcelona

Ensuring that tourism fits in better with the needs of the city

\section{4 major proposal to achieve objectives}

To determine the impact and effects generated by tourism activity in the city itself

To reflect on the model of tourism in the city

To set the tourism development of the city within a framework of sustainable growth

To foster the positive involvement of the community in the city's tourism project.

The aim of the tourism model implemented was to express the type of tourism Barcelona aspired to, as well as the role this activity has to play in the city throughout its development.

Three core principles defined the tourism model:

- Coherence with the city model, based on a reciprocal feedback relationship, as well as in positive synergies in a bi-directional way. In this sense, the tourism model is part of the city model while helping to shape it, so that the coherence between both models is a key aspect.

- The balanced relationship between visitors and residents, with no competition or conflict between them, based on cultural and economic exchanges and reciprocal contributions, understood as an enriching and mutually constructive experience.

- Economic, social, environmental and heritage sustainability, in order to fulfill the needs of future generations while satisfying present needs.

As seen in the objectives and principles, one of the strategic lines was to identify sustainability as a key factors for the sector's competitiveness; which made it understandable that in 2011 Barcelona applied for a certification based on destination criteria: Biosphere Destination (before called Biosphere World Class Destination), which is the case being studied. This certification was renewed for three more years on 2014.

Furthermore, in October 2013, private and public sector involved in tourism signed the document "Vision for Responsible Tourism in Catalonia 2020: the Barcelona Declara- 
tion" in which they agreed on the criteria, directives and commitments to be implemented in the development in the sort of tourism captured by the slogan "best place to live, best place to visit", which implies analysing the local resident, the environment and the tourists. And on a regional level, in November 2012, the regional Government established the Catalonia Tourists tax, which is basically a tax on stays in tourist establishments. The aim is to promote Catalonia region, encourage sustainable tourism, maintain and create tourism resources. However, in Barcelona in particular, all the income collected from the tax is destinated to create infrastructures to easy tourism congestion and better distribution of the wealth coming from tourism, making tourism more manageable for locals.

Biosphere Destination Standard: As seen on the Strategic Plan, Barcelona is oriented to achieving sustainability, in its broader meaning on the city. One of the measures was to obtain an ecolabel. In June 2011 Barcelona was the first city in the world to obtain the Biosphere Destination Standard (nowadays there are other 13 Spanish destinations also certified).

This certification was awarded by the ITR (Responsible Tourism Institute), an organization born after the World Conference on Sustainable Tourism (1995) sponsored by UNESCO. The main objective of the ITR has always been promoting the principles of the "World Charter For Sustainable Tourism" by implementing actions and programmes for sustainable development in the tourism industry. For this purpose, ITR follows the recommendations of the United Nations Conference for the protection of the environment and development (Rio-1992), and the guidelines of various programs of the WTO (World Tourism Organization) and UNESCO on sustainable development and protection of cultural and natural heritage. Therefore, currently the ITR maintains a cooperation agreement with UNESCO and is affiliated to the World Tourism Organization UNWTO, and member of the Global Sustainable Tourism Council (GSTC).

ITR claims that one of the most important challenges of today, and a responsibility of all stakeholders in tourism, is designing sustainable tourism patterns that allow you to develop "products" and "sustainable destinations".

Probably, that is the reason why the ITR created and developed the Responsible Tourism System (STR), which is recognized under the brand BIOSPHERE RESPONSIBLE TOURISM. This certification emerged as the answer to establish criteria for sustainable behaviour in the international tourist business. Therefore, the STR promotes sustainable tourism products.

The Biosphere certification is built on standards (for destinations, hotels, tour operators, mobility, holiday rental houses and visitor centers) based on the UN's 17 Sustainable Development Goals (SDG) of the 2030 Agenda, following the guidelines and recommendations of the World Charter for Sustainable Tourism +20 proclaimed in World Summit on Sustainable Tourism sponsored by COP21 (Climate Change Conference, Paris 2015), UNESCO, UNWTO and UNEP.

ITR highlights some of the benefits of applying this certification (ITR, 2016):

- Complete field of action (three sustainability pillars)

- Less paperwork due to its orientation to results

- Not too high implementation costs

- Preservation and efficient management of natural resources 
- Protection of the patrimony and cultural diversity

- Improvement of the quality life of the local community

- Resource efficiency (energy, water, emissions, waste, consumption, etc)

- Maximization of the touristic experience for the visitor

- Improvement of the tourism quality

- Increase in the visitor's confidence

- Compatible with other certifications (ISO 9001, ISO 14001, EMAS, etc.)

With Biosphere Destination Standard, Barcelona intended to construct a quality tourism model for promoting a balance between city residents and visitors while ensuring sustainability. The conservation and protection of the natural and cultural heritage of the destination, as well as its local traditions, was also highlighted.

\section{METHODOLOGICAL APPROACH}

The purpose of this section has been to challenge the Biosphere Destination Standard to see its authenticity, and to do so, key stakeholders have been interviewed in order to see their implication with the project. Besides, two other measures have been undertaken to prove its reliability.

First a focus group with the city stakeholders has been held, to determine if they were actually involved in this plan together with the DMO and if they actually believed in its importance towards achieving sustainability. Finding out this is important because when stakeholders choose to oppose to sustainable tourism strategies, they present a barrier to its realisation; therefore, recognizing their role as stakeholders is crucial and they need to be involved during the whole process (Waligo et al. 2015). The two other measures have been:

To confront and pair up the set of criteria that Biosphere Destination Standard has, with the GSTC ones. As previously mentioned, the set of standards developed by ITR, fulfil the GSTC requirements and therefore this entity recognizes and approves them. In order to provide more information about this world guide accredited company, it can be said that the GSTC is a USA-registered non-profit organization that represents a diverse and global membership, including UN agencies, leading travel companies, hotels, country tourism boards, tour operators, individuals and communities. It establishes and manages global sustainable standards (for hotels and destinations) with the aim of increasing sustainable tourism knowledge and practices among public and private stakeholders. It can be believed that if the Biosphere standards meet the GSTC ones, they will be considered trustworthy.

To adapt the certification to Font's study about ecolabels: The players in tourism ecolabels. Font (2001), introduced the different factors that a well-planned and organized ecolabel must have. It is assumed that if Biosphere Destination Standard fulfils so, it will be showing its good design and credibility.

In addition to this, the author aspired to also determine the opinion and feelings of the local population towards tourism in Barcelona. In order to do so, a discussion is included in this section, where different national and international newspapers registering the locals point of view are analyzed. It is important to bear in mind, that tourism sustainability has three pillars: economic, environmental and local population. 


\subsection{Focus groups: Semi-structured interview}

Focus groups have been used as the primary method for data collection in many studies and they are commonly used in conjunction with other methods, as for instance, a questionnaire (Kelechikwu, 2012), which is exactly the case in this research. The primary data collection will be undertaken by semi-structured interviews (also referred as to qualitative research interviews) (King, 2004), where the researcher has a list of questions and topics. The means for the interview has been audio-recording (Saunders, Lewis, \& Thornhill, 2009), providing a permanent record and allowing the researcher to concentrate on the interview (Robson, 2002).

This non-standardized interview has been developed one to many (the other possible type is one to one), through group interview, as a focus group. This modality is used when there is a focus on a clearly defined topic and encompasses the need for an interactive discussion among participants (Carson, Gilmore, Perry, \& Gronhaug, 2001). They are encouraged to discuss and exchange points of view and perceptions. Focus groups involve different number of participants depending on the nature of the participants and the specific topic. Eleven informants were interviewed in this case, all from the same sector and interested in sustainability. Participants are normally chosen because they have certain characteristics in common related to the topic being discussed (Krueger \& Casey, 2000). In this case, the sample were main stakeholders of Barcelona's tourism industry. The location of the meeting was Barcelona Tourism Board (BTB). BTB helped with the selection of informants; the eleven informants selected were from different sectors within the tourism industry. It was also important to have representation of the public and private sector. All the companies participating in the focus group had EMAS (European Ecomanagement and Audit Scheme) certification; therefore, they had knowledge, awareness and compromise on sustainable tourism. The informants were important stakeholders of Barcelona, as detailed in the chart below (Table 3).

\subsection{Conducting interviews via focus groups}

In this section, the actual questions of the semi-structured interview are presented. Their aim is to get enough information from the stakeholders in order to see if they trust the certification and its implementation in Barcelona:

1. Barcelona Tourism Strategic Plan supports tourism sustainability. Do you believe that they are doing a good job? Why? Why not?

2. To what extent do certifications in general and especially Biosphere Destination Standard enhance sustainability in Barcelona?

3. Do you really believe that through certifications you can develop a more sustainable city?

4. It is known that applying sustainable measures is beneficial in a long-term period; yet, do you think that your companies would be interested in investing in order to adopt a certification criteria? 
Table 3

\section{LIST OF INFORMANTS}

\begin{tabular}{|c|c|}
\hline INFORMANT \& COMPANY & RELEVANCE \\
\hline $\begin{array}{c}\text { Informant } 1 \\
\text { Environmental Qualification Service } \\
\text { Environment and Sustainability } \\
\text { Secretary. }\end{array}$ & \multirow{2}{*}{$\begin{array}{l}\text { These institutions depend on the Catalonian } \\
\text { Government, and state the effort that the city is } \\
\text { undertaking in order to achieve sustainability. }\end{array}$} \\
\hline $\begin{array}{l}\text { Informant } 2 \\
\text { Qualification System Department } \\
\text { Environmental Quality General } \\
\text { Direction. }\end{array}$ & \\
\hline $\begin{array}{l}\text { Informant } 3 \\
\text { Pere Tarrés Youth Hostel }\end{array}$ & $\begin{array}{l}\text { Representation of the accommodation sector in } \\
\text { Barcelona (over } 16 \text { million overnight stays in 2013). } \\
\text { This youth hostel is concerned about sustainability and } \\
\text { all the electricity used is generated by solar panels. }\end{array}$ \\
\hline $\begin{array}{l}\text { Informant } 4 \\
\text { Palau de la Musica Catalana } \\
\text { (Catalan Music Palace) }\end{array}$ & $\begin{array}{l}\text { The Concert Auditorium was listed as a World Heritage } \\
\text { Site by UNESCO in } 1977 \text {. They offer a wide cultural } \\
\text { programme each year. - } 420.000 \text { people has visited the } \\
\text { Palau in } 2015 \text { ( } 10 \% \text { more than in } 2014)\end{array}$ \\
\hline $\begin{array}{l}\text { Informant } 5 \& \text { Informant } 6 \\
\text { Museu Nacional D’Art de Catalunya } \\
\text { (National Museum of Catalonian Art) }\end{array}$ & $\begin{array}{l}\text { Their primary task is to explain the general history } \\
\text { of Catalan art embracing different pieces (sculpture, } \\
\text { painting, drawing, engraving, posters, photography } \\
\text { and coinage). It received approximately } 718.230 \text { visits } \\
\text { in } 2015 \text {. }\end{array}$ \\
\hline $\begin{array}{c}\text { Informant } 7 \\
\text { Gran Teatro Liceu. (Great Liceu } \\
\text { Theatre) }\end{array}$ & $\begin{array}{l}\text { It has a wide yearly program, offering different } \\
\text { performances (opera, theatre, zarzuela, ballet, etc.) }\end{array}$ \\
\hline $\begin{array}{l}\text { Informant } 8 \\
\text { EMAS Club }\end{array}$ & $\begin{array}{l}\text { Catalonia has } 274 \text { companies which are part of the } \\
\text { EMAS club }\end{array}$ \\
\hline $\begin{array}{l}\text { Informant } 9 \\
\text { Share Barcelona Company }\end{array}$ & $\begin{array}{l}\text { It is a new company that organizes trips, trainings and } \\
\text { new experiences for all visitors interested in getting } \\
\text { familiar with the solutions developed in Barcelona to } \\
\text { create a more sustainable city model. }\end{array}$ \\
\hline $\begin{array}{l}\text { Informant } 10 \\
\text { Barcelona Tourism Board }\end{array}$ & Their importance is seen throughout this research. \\
\hline $\begin{array}{l}\text { Informant } 11 \\
\text { Art Centre Santa Mónica } \\
\text { (Santa Monica Art Centre) }\end{array}$ & $\begin{array}{l}\text { It is and art centre that received over } 173.000 \text { visits } \\
\text { in } 2015 \text {. }\end{array}$ \\
\hline
\end{tabular}




\subsection{Data analysis and findings}

In order to analyze the results, Denzin \& Lincoln (2005) refer to qualitative research as bricolage, the art of adapting and using a variety of materials and tools, and to the qualitative researcher as a bricoleur, someone who is skilled in the use and adaption of the tools. According to McGiven, (2006), "qualitative data analysis is one area of qualitative research where this bricolage approach is very much in evidence". This process of analyzing data is likely to begin at the same time as these data are collected continuing afterwards. Analysis of qualitative data is difficult and time consuming. There are no standard techniques or clearly defined procedures.

However, to make this data useful, they need to be analyzed and understood, taking into account the context and circumstances in which the data is gathered (Kelechikwu, 2012). After data have been collected in a focus group, and the audio-data have been transcribed, analyzed and interpreted, the Miles \& Huberman (1994) approach is used in this research, providing a general framework for conceptualizing qualitative data analysis, which is particularly useful in case studies. This method of analysis consists on "flows of activities": data reduction, data display, and conclusion drawing.

The whole transcription may be seen upon request to the author, below, a set of the most important and relevant stakeholder statements are exposed:

\section{Table 4 \\ STAKEHOLDERS STATEMENTS}

Informant 1: "Certifications are the way to prove that the actions are in the long run and you are actually doing what you say you are. You may say that you implement sustainability measures; however, without any certifications, that will be not possible to prove". "There is a tendency to proclaim yourself sustainable "I'm green". Anyone can say so, yet, there has to be an organization or scheme proving that you are actually following some parameters and controls. Otherwise, it would be very difficult to distinguish between sustainable and unsutainable companies".

Informant 3: First there needs to be an individual or company awareness. Once this awareness exists, then put it into practice. It is always a good idea to partner with expert institutions that lead you on the path of getting an accreditation. Yet, currently there is still room for awareness, right? There is a long path to walk in front of us still.

"Companies managed by young people are even more willing to obtain certificates. Young people are prescriptors of sustainability".

Informant 5: "There is no doubt that through certifications cities achieve sustainability. They have come to a compromise and they have to implement a specific management system. Without certifications, not many people would voluntarily undertake these measures".

Informant 7: "Certifications bring you into line to achieve sustainability".

Informant 8: "In Barcelona there are some companies that believe in sustainability and have a certification or are working to get one. Somehow, without sustainability, tourism would not work in the future". "If you have the EMAS label for instance on your door, your neighbor might see it and copy your action". "Certifications are also useful for dissemination, because there is lack of communication. If you have obtained an ecolabel it means that you have properly managed wastes, and reduced water and electricity consumption and by posting the ecolabel on your door, you might influence others" 
"Having a certification might be an inspiration for others. If you don't communicate what you do,
it will stay indoors and you will not have the potential of influencing others to do the same". "We
need to pay attention to analyzing tourism impact in Barcelona. This is a big problem that will
grow even more unless we take measures, becoming even more serious".
Informant 9: "The good thing about certifications is that different companies share values,
principles and all of them (independently from the certification) work on environmental issues,
trying to reduce energy, water and waste consumption". "The environmental aspect of tourism is
growing in importance in the city". Communication is also easier through certifications, because
if you find a person, even if is from another sector or from a hotel instead of a museum, you will
be speaking the same language because at the end the sustainability problems to confront are the
same.
Informant 10: "My experience with Biosphere World Class Destination is that it precisely forces
the city (due to the fact that it is a destination certification) to achieve the collaboration among the
city stakeholders, you would not otherwise".

After studying some of the stakeholders answers, a few ideas can be identified:

- They do believe in sustainability.

- They do believe in certifications and their importance.

- They do believe that sustainability can be achieved through certifications.

- They do believe that certification actions are long-lasting.

- They believe that this certification will bring sustainability to the city.

Challenging the certification

As explained at the beginning of this methodology section, the Biosphere Destination Standard is called into question by two means in order to evaluate its reliability and trustworthiness:

- By adapting the certification to Font's study about ecolabels: The players in tourism ecolabels.

- By comparing it with one of the most recognized and well known destination criteria (GSTC).

\subsection{The players in Tourism Ecolabels vs Biosphere Destination Standard. Pairing up criteria}

It can be appreciated that the certification apparently fulfils the different requirements and steps that Font (2001) suggested as necessary to be a solid and respectable certification.

In table 5, the criteria for the Biosphere Destination Standard are paired up and therefore compared with the GSTC criteria for destinations. The purpose is to challenge the Biosphere set of criteria in order to find out if they follow the leaders set of standards.

The completed chart can be seen in the Appendix 1. Below, just an example has been developed, for the reader to understand how this comparison has been done. 
Figure 2

\section{THE PLAYERS IN TOURISM ECOLABELS VS. BIOSPHERE DESTINATION STANDARD}
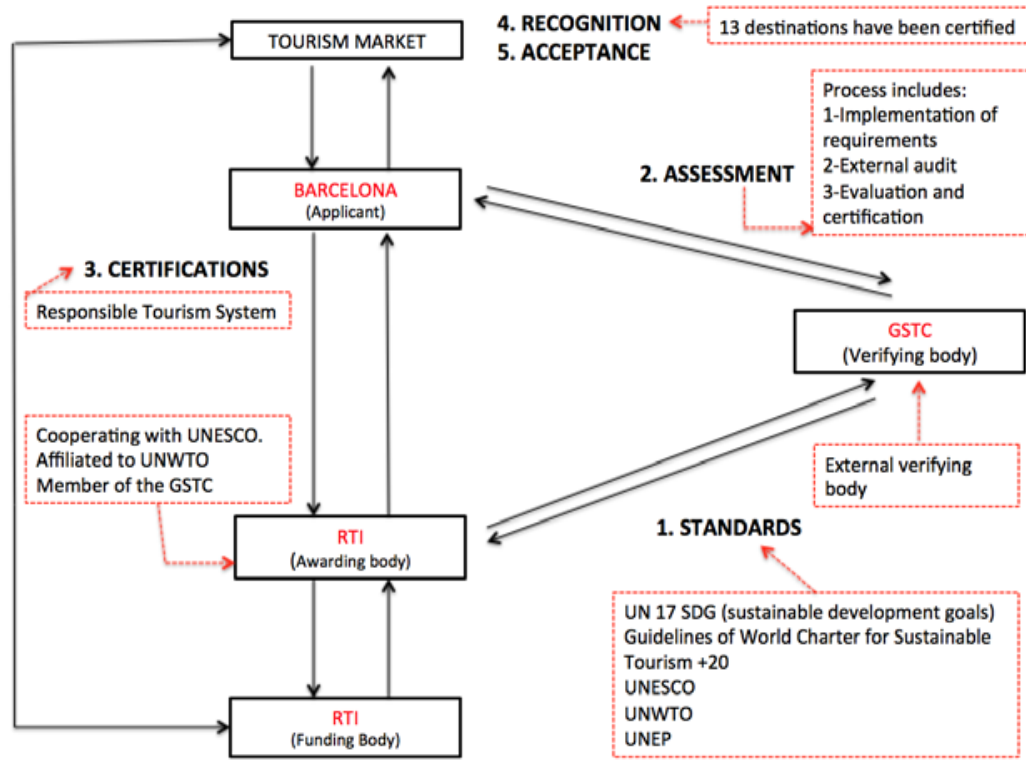

Table 5

SET OF CRITERIA COMPARISON AND PAIRING (EXAMPLE)

\begin{tabular}{|c|c|}
\hline $\begin{array}{l}\text { Set of criteria: A } \\
\text { GSTC criteria }\end{array}$ & $\begin{array}{l}\text { Set of criteria: B } \\
\text { BIOSPHERE criteria }\end{array}$ \\
\hline $\begin{array}{l}\text { A.2. Destination management organization } \\
\text { The destination has an effective } \\
\text { organization, department, group, or } \\
\text { committee responsible for a coordinated } \\
\text { approach to sustainable tourism, with } \\
\text { involvement by the private sector and } \\
\text { public sector. This group is suited to the } \\
\text { size and scale of the destination, and } \\
\text { has defined responsibilities, oversight, } \\
\text { and implementation capability for the } \\
\text { management of environmental, economic, } \\
\text { social, and cultural issues. This group's } \\
\text { activities are appropriately funded. }\end{array}$ & $\begin{array}{l}\text { Establishing a responsible functional } \\
\text { organization } \\
\text { A.3.1. The body responsible for the responsible } \\
\text { tourism Management System in the destination } \\
\text { has to establish a tool (organization, department, } \\
\text { group or committee) according to the size and scale } \\
\text { of the destination that allows the participation and } \\
\text { collaboration of the private and public tourist sector } \\
\text { and the local government for the administration } \\
\text { of all issues related to sustainable development } \\
\text { and its variables. This group should define its } \\
\text { responsibilities, its monitoring and its ability to } \\
\text { perform in terms of environmental, economic, } \\
\text { social and cultural management. The organization's } \\
\text { activities must be appropriately funded. }\end{array}$ \\
\hline
\end{tabular}


IN-A2.a.An organization has responsibility for a coordinated approach to the management of sustainable tourism

IN-A2.b. The private sector and public sector are involved in the organization and coordination of tourism

IN-A2.c. The tourism organization is suited to the size and scale of the destination

IN-A2.d. Individuals within the tourism organization have assigned responsibilities for sustainable tourism

IN-A2.e. The tourism organization is appropriately funded

A.14 Promotion

Promotion is accurate with regard to the destination and its products, services, and sustainability claims. The promotional messages treat local communities and tourists authentically and respectfully.
This can be done through work groups, sessions, agreements, collaborations, etc., and it is a necessary point in the implementation of measures for the "elements of the system", tour operators and travel agencies.

\section{Responsible marketing}

A.4.1. All promotional messages of the destination have to treat local communities authentically and respectfully. The promotional messages also must treat local tourists respectfully.

It's seen that every single section on set of criteria A (GSTC) has been paired up with at least one section of the set of criteria B (Biosphere), meaning that same or similar actions need to be taken in both cases. Even more, the set of criteria B has 66 extra sections with further actions to be taken towards sustainability. Therefore as GSTC criteria follows the WTO destinations level indicators and ITR has also followed the GSTC criteria when creating Biosphere Destination Standard, it can be stated that this certification perfectly meets the needed requirements to be accurate and reliable.

\section{DISCUSSION. THE THIRD PILLAR OF SUSTAINABILITY: LOCAL POPU- LATION}

Through this research, it has been confirmed that the certification has the guarantees needed to be trustworthy. It has an important awarding body and the standards are backed up by important organizations like United Nations or the World Tourism Organization.

On the other hand, the city stakeholders together with the DMO have put great effort on planning tourism, they have followed a well-designed Strategic Plan, as well as taken the necessary actions, like getting a certification, toward sustainability. However, there are several facts indicating that Barcelona is not at its best shape in regards to tourism.

Environmentally wise, the air is getting more and more polluted, the carbon dioxide levels (caused by heatings, cars, boats, electricity generation, etc.) are reaching $56 \mu \mathrm{g} /$ $\mathrm{m}^{3}$ in the Eixample (most touristic area) when the WHO (World Health Organization) states $40 \mu \mathrm{g} / \mathrm{m}^{3}$ as an average. Regarding the ozone levels, the maximum recommended is $100 \mu \mathrm{g} / \mathrm{m}^{3}$ average every 8 hours. Barcelona is far from these levels $\left(46 \mu \mathrm{g} / \mathrm{m}^{3}\right)$, yet it has been constantly growing despite the implementation of the Biosphere Destination 
Standard that has a specific requirement to take care of this: Standard D.7.2., "The destination must ensure a healthy air quality, free of pollutants" (Ajuntament de Barcelona, 2016).

In regards to tourism satisfaction, the annual tourism activity poll shows that tourists rate Barcelona 8.6 but complain about its massification. Even more, $58 \%$ of the visitors believe that the city is too crowded. Barcelona has been classified as the 4th destination that disappoint tourists the most. Tourists are unsatisfied with massification and insecurity. Moreover, $39 \%$ of tourists believe that prices are too high considering the quality that they receive. A clear example of why tourists are giving negative results to Barcelona is that eight out of ten people walking down the Ramblas are tourists (Chibás, 2004). According to Labadi \& Logan (2015) "bye bye Barcelona" focusses on the darker aspects of mass tourism in Barcelona; this is why this resource has been used in this discussion. The certification has a whole section to ensure that this does not happen: A.12.1. Destinations should have mechanisms to monitor, assess and publicly report visitor satisfaction, and, if necessary, to take action to improve visitor satisfaction and promote the quality of tourism services at all levels.

Obviously, another aspect to take into account, and even more when talking about sustainable tourism, is the local population. In the case of Barcelona, even though tourism is creating 2 million euros a day, representing 12\% of Barcelona's GDP, local population are highly unsatisfied with the situation. A percentage of $13 \%$ of Barcelona residents assess as negative or very negative the fact that Barcelona is a world known destination. Even more, mass tourism is the second thing that most worries Barcelona citizens after unemployment (Genillo, 2016). One of the main impacts of this massification is many legal and illegal touristic apartments that are appearing everywhere in the city. Locals are selling their houses and leaving the centre traditional neighbourhoods (Palazzi, 2016). For instance, $51 \%$ of the properties in Ciutat Vella neighbourhood are touristic. This is causing a loss of identity in the city. A neighbour says "We are losing the small traditional businesses, all you can see now are souvenir shops everywhere and fast food restaurants. Prices are rising making the daily life impossible as there are floods of people everywhere" (Chibás, 2004).

One representative of the neighbourhood associations says: "This is an invasion. We have lost The Ramblas, La Boquería market, Parc Güell...we are simply losing our city after tourists" (EVDCV, 2013). At the moment there are plenty of neighbour associations fighting against mass tourism as ABTS (neighbourhood assembly for a sustainable tourism) or ABA (Affected neighbourhood assembly). Furthermore, on many occasions, neighbours have organized protests in front of the city council, claiming a change in tourism policy.

In Barcelona and anothers urban destiny we have not forget the extreme importance of the process of renovation/restructuration of existing, consolidated tourist destinations both as regards their tourism competitiveness and, especially, due to the consequences - often in the form of new conflict - than these processes have in environmental and social terms (Antón et al, 2011).

According to López-Palomeque (2015), the association "turismo-conflicto" (tourismconflict) has been present in the debates regarding Barcelona's tourism model, leading to many of its members suffering from tourism phobia. Once more, it is seen that the 
certification covers this problem: Tools for civic participation in tourism and measurement of the satisfaction of the local community B.4.1. The destination must have a system that promotes public participation in destination planning and decision making.

All these news regarding Barcelona and its neighbour also sounds internationally: "Will the citizens of Barcelona revolt against soaring tourist numbers? With the Catalonian city hosting five times as many visitors as 20 years ago, there is a feeling among some locals that the financial benefits are not worth the hassle" (Burgen, 2015). "Nobody goes there anymore, it's too crowded" (Gulliver Business Travel, 2015). "Saturated by tourists, Barcelona wishes to revise its tourism model" (Thibaud, 2015). Furthermore, in November 2012 the regional government introduced the Catalonia Tourism Tax, which in Barcelona was used to easy tourism congestion. Also, in October 2013, private and public sector involved in tourism, in an attempt to ensure that tourism was growing in a satisfactory way in terms of sustainability, signed a document forecasting Barcelona's situation in 2020 taking into account local residents, the environment and the tourists.

If on the one hand, Biosphere Destination Standard has all the needed requirements to prevent this problems and on the other hand, Barcelona has made a great effort trying to control this situation from the Strategic plan in 2010; what went wrong? why is the city massified with tourism and both, tourists and locals are unsatisfied?

\section{CONCLUSION}

The aim of this study was to find out if by implementing an ecolabel in a destination, applying an SDM model, tourism sustainability increases. The case being studied has been Barcelona, which in the last five years has increased number of visitors and overnight stays over $110 \%$.

As previously seen, back in 2010, Barcelona implemented a well-structured tourism strategic plan, where one of the core objectives was ensuring that tourism fits better with the needs of the city. In order to achieve this objective, two of the major proposals were to determine the impacts of tourism in the city and to set tourism development within the framework of sustainable growth. It is seen that even then, Barcelona tourism board and other stakeholders were concerned about tourism sustainability. One of the first measures to ensure this sustainability, was the implementation of the Biosphere Destination Standard. This ecolabel has been challenged throughout this research in two ways: by adapting it to Font's study about ecolabels and by confronting it with one of the most recognized and well known destination criteria (GSTC, 2016). In both cases, the result was satisfactory, meaning that the ecolabel can be believed to be trustworthy and reliable.

As the aim of the study is to determine whether ecolabels enhance sustainability in a destination, key tourism stakeholders of the city were interviewed to get their opinions. It has been seen after analysing the results that they have been very assertive on their answers, having no doubt of the impact of ecolabels towards sustainability.

After observing that the DMO has made a great effort to plan and structure Barcelona tourism in a sustainable way with future perspectives and that key stakeholders are bonding together to implement a sustainable certification in the city, it can be surmised that ecolabels improve sustainability. 
However, it is important to bear in mind that tourism sustainability not only applies to the environment as it is commonly thought but also to two other aspects as the economy and the local population. With over eight million visitors (spending 2 million euros a day in the city) and well organized and structured DMO, it can be assumed that the economic pillar of sustainability is somewhat covered. Nevertheless, the third pillar regarding local population is the one that appears to also be failing, as the local population seems not to be satisfied at all with how the city is getting so many tourism, that the essence of the city is being lost. As seen on the discussion section of this research, the certification has standards to prevent this issue; yet, they do not seem to be enough.

Moreover, Hughes et al (2015) believe that despite the new trends, there is still a wide gap between theory and practice in sustainable tourism as considering the number of international arrivals, the world's tourism activity can be describe as mass tourism. Taking into account Hughes studies and all the research and fundamentals seen in this paper, it will be easy to believe that Barcelona is just a consequence of a worldwide phenomenon that cannot be controlled from just one destination and even less through tourism management tools. Accordingly, taking into account that the aim of the study was to discern whether ecolabels increase sustainability in a destination, out of this research, it can be stated that in some regard it does; however, fulfilling the three pillars of sustainability with just one ecolabel, taking into account the world trend towards mass tourism, it will be almost impossible to believe so.

In conclusion, the strategic plan together with the ecolabel have not achieved the expected outcome. Even though the municipality is receiving millions of euros a year from tourism activity, the wealth redistribution and the alleviation of massification has not been achieved. Even more, this massification is making locals dislike tourists and its activities. Barcelona, has not been able to hold this invasion phenomenon that is taking place in many urban destinations these days.

New sustainable measures are needed to meet the challenges set by the Barcelona Tourism Strategic Plan 2020 (Ajuntament de Barcelona, 2017).

\section{REFERENCES}

AJUNTAMENT DE BARCELONA. (2010): Pla Estratègic de Turisme de la Ciutat de Barcelona 2010-2015. Ajuntament de Barcelona. Turisme de Barcelona.

AJUNTAMENT DE BARCELONA. (2016): Anuario Estadístico de la ciudad de Barcelona, 2016. Territorio, clima y medio. Turisme de Barcelona.

AJUNTAMENT DE BARCELONA. (2017): Plan Estratégico de Turismo 2020. Resumen Ejecutivo, marzo 2017. Dirección de Turismo Gerencia de Empresa y Turismo.

ANTÓN, S., RULLÁN, O. and VERA, S. (2011): «Mass Tourism Development on the Mediterranean Coast», Tourism Geographies, Vol. 13 (3), pp. 495-501.

ARCHER, B. (1996): «Sustainable tourism: An economist $>$ s viewpoint, Sustainable tourism in islands \& small states: Issues and policies». Pinter, New York, pp. 6-17.

AYUSO, S. (2007): «Compairing voluntary policy instruments for sustainable tourism: The experience of the Spanish hotel sector», Journal of Sustainable Tourism, 15, pp. 144-159. 
BARCELONA TURISME. (2010a): Turisme Barcelona 2015. City of Barcelona Strategic Tourism Plan. Diagnosis and strategic proposal (Executive summary). Turisme de Barcelona.

BARCELONA TURISME. (2010b): Estadísticas de turismo de Barcelona. Retrieve from: http://professional.barcelonaturisme.com/files/8684-906-pdf/Est2010b.pdf

BARCELONA TURISME. (2016): Estadísticas de turismo de Barcelona; ciudad y entorno. Retrieve from: http://professional.barcelonaturisme.com/imgfiles/estad/ Est2015.pdf

BRAMWELL, B. and LANE, B. (1993): «Sustainable tourism: An evolving global approach». Journal of Sustainable Tourism, 1 (1), pp. 6-16.

BRAMWELL, B. and LANE, B. (2000): «Tourism, collaboration \& partnerships: Politics, practice and sustainability». UK: Clevedon.

BUCKLEY, R.C. (2001): «Major Isues in Tourism Ecolabelling». In: X. Font, \& R. Buckley, Tourism Ecolabelling. Certification and Promotion of Sustainable Management pp. 19-26. Wallingford: CABI Publishers.

BUCKLEY, R. C. (2002): «Tourism ecolabels», Annals of Tourism Research, 29, pp. 183-208.

BUCKLEY, R. (2012): «Sustainable tourism: Research and reality», Annals of Tourism Research, 39(2), 528-546.

BURGEN, S. (2015): «Will the citizens of Barcelona revolt against soaring tourists numbers». The Guardian. Retrieve from: https://www.theguardian.com/travel/2015/jun/28/ will-people-barcelona-revolt-against-soaring-tourist-numbers

BUTOWSKI, L. (2010): Sustainable Tourism. A model approach. Warsaw, Poland: Vistula University in Warsaw.

CARSON, D; GILMORE, A; PERRY, C. and GRONHAUG, K. (2001): Qualitative Marketing Research. London: Sage Publications.

CASELlAS, A., DOT JUTGLA, E. and PALLARES-BARBERA M. (2010): «Creación de imagen, visibilidad y turismo como estrategias de crecimiento económico de la ciudad». Finisterra XLV (90) pp. 153-172.

CASTELLANI, V. and SALAS, S. (2010): «Sustainable performance index for tourism policy development», Tourism Management, 31(6), pp. 871-880.

CERNAT, L. and GOURDON, J. (2012): «Paths to success: Benchmarking cross-country sustainable tourism», Tourism Management, 33, pp. 1044-1056.

CHIBÁS, E. (2004): «Bye Bye Barcelona». Retrieve from: http://www.byebyebarcelona. com/eldocumental

COMISIÓN EUROPEA (2013): European Tourism Indicators System for sustainable destination management (ETIS). Luxemburgo: Oficina de Publicaciones de la UE, pp. 56.

DENZIN, N. and LINCOLN, Y. (2005): «Introduction: The discipline and practice of qualitative research». In: N.K. Denzin, Y.S. Lincoln (Eds.), The sage handbook of qualitative research (3rd ed.) (pp. 1-32). London: Sage.

DIAMANTIS, D. and WESTLAKE, J. (2001): «Ecolabelling in the Context of Sustainable Tourism and Ecotourism». In X. Font, \& R. Buckley, Tourism Ecolabel. Certification and Promotion for Sustainable Management, pp. 27-40. Wallingford: CABI publishing. 
EUROPEAN COMISSION ENVIRONMENT. (2012): EMAS. Retrieved from: http:// ec.europa.eu/environment/emas/index_en.htm

EVDCV. (2013): Europa Press. Entidades Vecinales Distrito Ciutat Vella. Retrieved from: https://www.youtube.com/watch?v=K3HgtfUWNmI

FAIRWEATHER, J. MASSLIN, C. and SIMONS, D. (2005): «Environmental Values and response to Eco-labels among international visitors to New Zeeland», Journal of Sustainable Tourism, 13 (1): pp. 82-98

FERNÁNDEZ, J.I.P. and RIVERO, M.S. (2009): «Measuring tourism sustainability: proposal for a composite», Tourism Economics, 15, pp. 277-296.

FERNÁNDEZ, A., FORONDA, C., GALINDO, L. and GARCÍA, A. (2017): «Developing a system of territorial governance indicators for tourism destinations», Journal of Sustainable Tourism, 25 (9), pp. 1275-1305.

FONT, X. (2001): «Regulating the Green Message: the players in Ecolabelling». In Font, X. \& Buckley, R., Tourism Ecolabelling. Certification and Promotion of Sustainable Management, pp. 1-17. Wallingford: CABI.

FONT, X. (2002): «Environmental certification in tourism and hospitality: progress,process and progress», Tourism Management, 23, 197-205.

GLOBAL SUSTAINABLE TOURISM COUNCIL. (2016): GSTC Destination Criteria. Retrived from: https:/www.gstcouncil.org/gstc-criteria/gstc-destination-criteria/

GENILLO, E. (2016): «El turismo masivo ya es la segunda preocupación de los barceloneses». La Razón. Retrieved from: http://www.larazon.es/local/cataluna/elturismo-masivo-ya-es-la-segunda-preocupacion-de-los-barceloneses-GB13657313\#. Ttt1xpFpW12bout

GONZÁLEZ, S. (2011): «Bilbao and Barcelona 'in Motion'. How Urban Regeneration 'Models' Travel and Mutate in the Global Flows of Policy Tourism», Urban Studies, 48, pp. 1397-1418.

GREEN, H. (1995): «Planning for sustainable tourism development». In C. Hunter and H. Green (eds.) Tourism and the environment: a sustainable relationship?, pp. 93-121. London: Routledge.

GULLIVER BUSINESS TRAVEL. (2015): «Nobody goes there anymore, it's too crowded». The Economist. Retrieved from: http://www.economist.com/blogs/gulliver/2015/06/tourism-barcelona

HALL, C. (2005): Tourism Rethinking the social science of mobility. Prentice - Hall: Harlow.

HAMELE, H. (2001): «Ecolabels for tourism in Europe: The European ecolabels for tourism». In X. Font, and R. Buckley (Eds.), Tourism Ecolabelling: Certification and promotion of Sustainable Management. Wallinford: CAB International.

HEDRICK-WONG, Y. and CHOONG, D. (2016): «Global Destination Cities Index by Master Card». Retrieved from http://newsroom.mastercard.com/wp-content/ uploads/2016/09/FINAL-Global-Destination-Cities-Index-Report.pdf

HONEY, M. and STEWARD, E. (2002): «The evolution of green standards for tourism». In M. Honey (Eds.), Ecotourism and certification: setting standards in practice (pp.3372). Washington DC: Island Press. 
HUGHES, M., PFORR, C. and WEAVER, D. (2015): «Confronting the reality of paradox in sustainable tourism». In M. Hughes, C. Pforr, and D. Weaver (Eds.), The practice of sustainable tourism: resolving the paradox, pp. 1-8. UK: Routledge.

INSTITUTO DE ESTADÍSTICA DE CATALUÑA (2016): Generalitat de Catalunya. Retrieved from http://www.idescat.cat/pub/?id=aec\&n=246\&lang=es

INE (2016): «Notas de Prensa: Movimientos turísticos en fronteras 2015». Retrieved from http://www.ine.es/daco/daco42/frontur/frontur1215.pdf

ITR. (2016): Lanzarote: ITR (Responsible Tourism Institute). Retrieved from http://www. institutoturismoresponsable.com/es

JARVIS, N., WEEDEN, C. and SIMCOCK, N. (2010): «The Benefits and Challenges of Sustainable Tourism Certification: A Case Study of the Green Tourism Business Scheme in the West of England», Journal of Hospitality and Tourism Management, 17 (1), 83-93.

KELECHIKWU, O. (2012): Mastering the art of sustainable business competitiveness. Trafford Publishing. USA.

KING, N. (2004): «Using interviews in qualitative research». In V. Cassell, Guide to Qualitative Methodss in Organizational Research. London.

KO, T.G. (2005): «Development of a tourism sustainability assessment procedure: a conceptual approach», Tourist Management, 26 (3), pp. 431-445.

KOZAK, M. and NIELD, K. (2004): «The role of quality and eco-labelling systems in destination benchmarking», Journal of Sustainable Tourism, 12 (2), pp. 138-148.

KOZAK, M. (2004): «Destination Benchmarking: Concepts, Practices and Operations». Wallingford, Uk: CAB International.

KRUGER, R. and CASEY, M. (2000): «Focus groups: A Practical Guide for Applied Research». Thousand Oaks, CA: Sage.

LABADI, S. and LOGAN, W. (2015): Urban Heritage, Development and Sustainability: International Frameworks, National and Local Government. Routledge.

LAZZERETTI, L. and PETRILLO, C. (Eds.) (2006): Tourism local systems and networking. Oxford, UK: Elsevier.

LIU, Z.H. and JONES, E. (1996): «A systems perspective of sustainable tourism». In M. Saayman (Ed.), Proceedings of the International Conference on Urban and Regional Tourism (pp. 209-21). South Africa: Potchefstroom.

LIU, Z. H. (2003): «Sustainable tourism development: a critique», Journal of Sustainable Tourism, 11(6), pp. 459-475.

LÓPEZ-PALOMEQUE, F. (2015): «Barcelona, de ciudad con turismo a ciudad turística. Notas sobre un proceso complejo e inacabado», Documents d'Anàlisi Geogràfica, 61 (3), pp. 483-506.

MALVIYA, S. (2005): «Tourism: Leisure and recreation». Dehli, India: Isha books.

MCGIVEN, Y. (2006): The Practice of Market and Social Research: An Introduction, $2^{\text {nd }}$ ed. Harlow: Pearson Education.

MCINTYRE, G.; HETHERINGTON, A. and INSKEEP, E. (1995): «On the need to reconceptualise sustainable tourism development», Journal of Sustainable Tourism, 3 (3), pp. 155-168. 
MICHAEL, E. (1999): «The Antiques Trade - A tourism generator». Tourism: Policy and Planning Conference, Proceedings of research Papers, Oamaru, N.Z., AugustSeptember.

MIDDLETON, V. (1997): «Sustainable Tourism: A marketing perspective». In M. Stabler, Tourism Sustainability. Principles to Practice (pp. 129-142). Wallingford: CAB International.

MIHALIČ, T. (1999): «Equity in outgoing tourism through tourism certificates». International Journal of Contemporary Hospitality Management, 11 (2/3), pp. 128-131.

MIHALIČ, T. (2004): «Implementation of environmental management in Slovenian Hotels through eco labels», in WTO Regional Conference for Europe on Public private partnerships for sustainable certification of tourism activities. Marianské Lanze, Czech Republic. WTO.

MILES, B. and HUBERMAN, A. (1994): Qualitative Data Analysis: An Expanded Sourcebook. London: Sage Publications.

MILLER, G. (2001): «The development of indicators for sustainable tourism: results of a Delphi survey of tourism researchers», Tourism Management, 22 (4), pp. 351-362.

NATUREFRIENDS INTERNATIONAL (2012): «Natures friends International Annual Report». Retrieved from: https://earthresponsible.files.wordpress.com/2013/03/rapport-of-activities-2012-nf.pdf.

PAMELA, A. (2001): «Environmental Management Tools in Canada: Ecolabelling and Best Practice Benchmarking». In X. Font, X. and R. Buckley, Tourism Ecolabelling. Certification and Promotion of Sustainable Management (pp. 141-164). Wallingford: CABI.

PAVLOVICH, K. (2003): «The evolution and transformation of a tourism destination network: The Waitomo Caves, New Zealand», Tourism Management, 24(2), pp. 203-216.

PULIDO, J.I. and SÁNCHEZ, M. (2009): «Measuring tourism sustainability: proposal for a composite index». Tourism Economics, 15(2), pp. 277-296.

ROBSON, C. (2002): Real World Research (2nd ed). Oxford: Blackwell.

RUHANEN, L., WEILER, B., MOYLE, B.D. and MCLENNAN, C.J. (2015): «Trends and patterns in sustainable tourism research: a 25-year bibliometric analysis», Journal of Sustainable Tourism, 23 (4), pp. 517-535.

SAXENA, G. (2005): «Relationships, networks and the learning regions: Case evidence from the Peak District National Park», Tourism Management, 26, pp. 277-289.

SAUNDERS, M., LEWIS, P. and THORNHILL, A. (2009): «Qualitative Methods for Accounting and Management. Compiled from Research Methods for Business Students». Pearson.

SCHIANETZ, K. and KAVANAGH, L. (2008): «Sustainability indicators for tourism destinations: A complex adaptive systems approach using systemic indicator systems», Journal of Sustainable Tourism, 16 (6), pp. 601-628.

SCHIANETZ, K., KAVANAGHB, L. and LOCKINGTON, D. (2007): «The Learning Tourism Destination: The potential of a learning organization approach for improving the sustainability of tourism destinations», Tourism Management, 28, pp. 1485-1496.

SINGH, R.K.; MURTY, H.R.; GUPTA, S.K. and DIKSHIT, A.K. (2009): «An overview of sustainability assessment methodologies». Ecological indicators, 9, pp. 189-212. 
SPITTLER, R. and HAAK, U. (2001): «Quality Analysis of Tourism Ecolabels». In R. Buckley, \& X. Font, Tourism Ecolabelling: certification and promotion of sustainable management (pp. 213-246). Wallingford: CABI Publishing.

THIBAUD, C. (2015): «Saturée par les tourites, Barcelone veut revoir son modèle», in 24 heures. Retrieved from: http://www.24heures.ch/monde/Saturee-par-les-touristesBarcelone-veut-revoir-son-modele/story/20757541

TOTH, R. (2000): «Elements of success and failure in certification/acreditation». In Ecotourism and sustainable tourism certification workshop. Monhonk Mountain House, New Platz, New York.

UNEP (Eds.). (1998): Ecolabels in the tourism industry. United Nations Environment Programme, Paris.

WAHAB, S. and PIGRAM, J.J. (1998): «Tourism and sustainability: Policy considerations». In S.Wahab and J.J. Pigram (Eds.), Tourism, Development and Growth. The Challenge of Sustainability (pp. 277-90). London: Routledge.

WALIGO, V., CLARKE, J. and HAWKINS, R. (2015): «Embedding stakeholders in sustainable tourism strategies», Annals of Tourism Research, 55, pp. 90-93.

WTO (2007): World Trade report 2007. Retrieved from: https://www.wto.org/English/ res_e/booksp_e/anrep_e/world_trade_report07_e.pdf 


\section{APPENDIX 1}

\begin{tabular}{|c|c|}
\hline Set of criteria: A. GSTC criteria & Set of criteria: B. BIOSPHERE criteria \\
\hline & $\begin{array}{l}\text { Responsible tourism policy } \\
\text { A.1.1. The destination has updated and accessible } \\
\text { management tools. }\end{array}$ \\
\hline \multirow[t]{3}{*}{$\begin{array}{l}\text { Sustainable destination strategy } \\
\text { The destination has established and is implementing } \\
\text { a multi-year destination strategy that is publicly } \\
\text { available, is suited to its scale; that considers } \\
\text { environmental, economic, social, cultural, quality, } \\
\text { health, and safety, and aesthetic issues; and was } \\
\text { developed with public participation. } \\
\text { IN-A1.a. Multi-year destination strategy that } \\
\text { includes a focus on sustainability and sustainable } \\
\text { tourism and includes environmental, economic, } \\
\text { social, cultural, quality, health, and safety issues } \\
\text { IN-A1.b. Multi-year destination plan or strategy } \\
\text { that is up-to-date and publicly available } \\
\text { IN-A1.c. Multi-year destination plan or strategy } \\
\text { that was developed with public participation } \\
\text { IN-A1.d. Political commitment to implement } \\
\text { the multi-year destination plan and evidence of } \\
\text { implementation }\end{array}$} & \\
\hline & $\begin{array}{l}\text { A.1.2. The destination shall have a Responsible } \\
\text { Tourism Policy that is documented and translated } \\
\text { into customary languages, formally approved by the } \\
\text { highest local authorities and communicated in an on- } \\
\text { going manner to residents and visitors. This policy } \\
\text { shall consist in a public manifestation of the strategy } \\
\text { adopted on sustainable tourism and will include the } \\
\text { commitments made concerning sustainable tourism, in } \\
\text { particular: } \\
\text { - Adoption of the principles of the World Charter for } \\
\text { Sustainable Tourism. } \\
\text { - Commitment to prevent negative impacts of policies } \\
\text { and activities, and to maximize positive } \\
\text { impacts. } \\
\text { - Commitment to on-going improvement in all areas } \\
\text { and environmental. } \\
\text { residents. }\end{array}$ \\
\hline & $\begin{array}{l}\text { Plan of action } \\
\text { A.2.3. The destination must elaborate and publicly } \\
\text { provide an operational document for continuous } \\
\text { improvement, a Plan of Action (PA), reflecting the } \\
\text { sustainable strategy of the destination. }\end{array}$ \\
\hline
\end{tabular}




\begin{tabular}{|c|c|}
\hline & $\begin{array}{l}\text { This Plan of Action must be developed with public } \\
\text { participation and be based on the Responsible Tourism } \\
\text { Policy and other issues related to environment, economy, } \\
\text { society, quality, health and safety, culture and aesthetics. } \\
\text { The PA must establish the specific targets and priorities } \\
\text { needed for the fulfilment of the commitments made. This } \\
\text { plan has to be structured with the following contents: } \\
\text { - A prioritised list of objectives to be achieved, specifying } \\
\text { the person responsible for achieving each point. } \\
\text { - A general description of the measures designed to achieve } \\
\text { these objectives and the deadlines and means } \\
\text { for implementing the measures. The total } \\
\text { timeline shall not exceed three years, by which } \\
\text { time the Plan must have been reviewed and } \\
\text { updated, setting new targets for improvement. } \\
\text { to monitor compliance and to take action if } \\
\text { necessary. } \\
\text { - A definition of the follow-up planned fore thesectives, } \\
\text { Tourism System (subsidies, information } \\
\text { campaigns, etc.). } \\
\text { - Promotion of responsible actions within tourism } \\
\text { continuous improvement of the destination in } \\
\text { all areas of tourism sustainability. They shall } \\
\text { be able to prove constant compliance with the } \\
\text { requirements of this standard. }\end{array}$ \\
\hline $\begin{array}{l}\text { A2 Destination management organization } \\
\text { The destination has an effective organization, } \\
\text { department, group, or committee responsible for } \\
\text { a coordinated approach to sustainable tourism, } \\
\text { with involvement by the private sector and public } \\
\text { sector. This group is suited to the size and scale of } \\
\text { the destination, and has defined responsibilities, } \\
\text { oversight, and implementation capability for the } \\
\text { management of environmental, economic, social, } \\
\text { and cultural issues. This group's activities are } \\
\text { appropriately funded. } \\
\text { IN-A2.a. An organization has responsibility for a } \\
\text { coordinated approach to the management of sustainable } \\
\text { tourism } \\
\text { IN-A2.b. The private sector and public sector are } \\
\text { involved in the organization and coordination of tourism } \\
\text { IN-A2.c. The tourism organization is suited to the size } \\
\text { and scale of the destination } \\
\text { IN-A2.d. Individuals within the tourism organization } \\
\text { have assigned responsibilities for sustainable tourism } \\
\text { IN-A2.e. The tourism organization is appropriately } \\
\text { funded }\end{array}$ & $\begin{array}{l}\text { Establishing a responsible functional organization } \\
\text { A.3.1. The body responsible for the responsible tourism } \\
\text { Management System in the destination has to establish } \\
\text { a tool (organization, department, group or committee) } \\
\text { according to the size and scale of the destination that } \\
\text { allows the participation and collaboration of the private } \\
\text { and public tourist sector and the local government for } \\
\text { the administration of all issues related to sustainable } \\
\text { development and its variables. This group should define } \\
\text { its responsibilities, its monitoring and its ability to perform } \\
\text { in terms of environmental, economic, social and cultural } \\
\text { management. The organization's activities must be } \\
\text { appropriately funded. } \\
\text { This can be done through work groups, sessions, } \\
\text { agreements, collaborations, etc., and it is a necessary point } \\
\text { in the implementation of measures for the "elements of the } \\
\text { system", tour operators and travel agencies. }\end{array}$ \\
\hline
\end{tabular}




\section{A14 Promotion \\ Promotion is accurate with regard to the destination and its products, services, and sustainability claims. The promotional messages treat local communities and tourists authentically and respectfully.}

\section{Responsible marketing}

A.4.1. All promotional messages of the destination have to treat local communities authentically and respectfully. The promotional messages also must treat local tourists respectfully.
IN-A14.a. Destination promotional messages that represent local communities and visitors authentically and respectfully

IN-A14.b. Destination promotional messages that are accurate in their description of products and services
A.4.2. Promotional information has to include true, clear and accurate information about services, products, environmental quality, local communities and other sustainability specifications of the offer. Furthermore, the information provided through different channels should not create expectations that cannot be met or ambiguously describe the different aspects of the destination's commitment and sustainable offer.

\section{A3 Monitoring}

The destination has a system to monitor, publicly report, and respond to environmental, economic, social, cultural, tourism, and human rights issues. The monitoring system is reviewed and evaluated periodically.

IN-A3.a. Active monitoring and public reporting of environmental, economic, social, cultural, tourism, and human rights issues

IN-A3.b. Monitoring system is reviewed and evaluated periodically

IN-A3.c. Tourism impact mitigation procedures funded and active

A4 Tourism seasonality management

The destination dedicates resources to mitigate seasonal variability of tourism where appropriate, working to balance the needs of the local economy, community, cultures and environment, to identify year-round tourism opportunities.

IN-A4.a. Specific strategy for marketing offseason events and attracting year-round visitors

\section{Monitoring plans for sustainable tourism}

A.5.1. The body responsible for the responsible tourism Management System in the destination has to establish a programme to assess and publicly report the commitments made and their corresponding progress in terms of sustainable tourism development (environment, society, economy, culture, tourism and human rights), as well as give an answer to any new topic that could arise. Such system of indicators, which should, to the extent feasible, be quantifiable, will be directly developed by the district officers. The monitoring system is periodically reviewed and evaluated.

\section{Prevention of seasonality}

A.6.1. Programmes has to be developed in order to mitigate seasonal variability of tourism where appropriate, working to balance the needs of the local economy, community, cultures and environment, identifying year-round tourism opportunities, such as the creation of diversified tourism products and a complementary offer.

\section{Legal and regulatory requirements}

A.7.1 The different departments with any kind of tourist responsibility at the destination must ensure the constant knowledge of all applicable legal and regulatory requirements in terms of sustainability in order to ensure compliance. They must therefore keep an up-to-date record, which includes all of them in a clear and understandable way. 


\section{A7 Planning Regulations}

The destination has planning guidelines, regulations and/or policies that require environmental, economic, and social impact assessment and integrate sustainable land use, design, construction, and demolition. The guidelines, regulations and/or policies are designed to protect natural and cultural resources, were created with local inputs from the public and a thorough review process, are publicly communicated, and are enforced.

IN-A7.a. Planning or zoning guidelines, regulations and/or policies that protect natural and cultural resources

IN-A7.b. Guidelines, regulations, and/or policies that address sustainable land use, design, construction, and demolition

IN-A7.c. Planning guidelines, regulations, and/or policies were created with local inputs from the public and a thorough review process

IN-A7.d. Planning guidelines, regulations, and/ or policies are publicly communicated and are enforced

A9 Property acquisitions

Laws and regulations regarding property acquisitions exist, are enforced, comply with communal and indigenous rights, ensure public consultation, and do not authorize resettlement without prior informed consent and/or reasonable compensation.

IN-A9.a. Policy or legislation, including enforcement provisions, exist

IN-A9.b. Policy or legislation that considers indigenous rights, ensures public consultation and authorizes resettlement only when there is informed consent and/or reasonable compensation

A5 Climate change adaptation

The destination has a system to identify risks and opportunities associated with climate change. This system encourages climate change adaptation strategies for development, siting, design, and management of facilities. The system contributes to the sustainability and resilience of the destination and to public education on climate for both residents and tourists.

IN-A5.a. Current system for climate change adaptation and risk assessment

IN-A5.b. Laws or policies to mitigate climate change and encourage technologies to mitigate climate change

IN-A5.c. Program to educate and raise awareness among the public, tourism enterprises, and visitors about climate change
A.7.2. The destination has planning guidelines, regulations and/or policies that require environmental, economic, and social impact assessment and integrate sustainable land use, design, construction, and demolition. There must also be laws and regulations regarding property acquisitions, always complying with communal rights, ensuring public consultation, and not authorizing resettlement without prior informed consent and/or reasonable compensation.

The guidelines, regulations and/or policies are designed to protect natural and cultural resources, were created with local inputs from the public and a thorough review process. This guidelines, regulations and/or policies are publicly communicated, and are enforced.
A.8.1. The body responsible for the responsible tourism Management System at the destination has to establish programmes designed to identify risks and opportunities associated with climate change. This system encourages climate change adaptation strategies for development, siting, design, and management of facilities. It will counter all potential negative impacts that tourism may have on climate change and other environmental crisis situations.

The system contributes to the sustainability and resilience of the destination and to public education on climate for both residents and tourists. This type of programmes may include the adoption of activities related to environment, implementation and use of efficient technologies, awareness campaigns, etc. If the destination considers it appropriate, all these measures can be developed together with other local authorities and/or groups. 


\begin{tabular}{|c|c|}
\hline \multirow[t]{5}{*}{$\begin{array}{l}\text { D3 Wildlife protection } \\
\text { The destination has a system to ensure compliance } \\
\text { with local, national, and international laws and } \\
\text { standards for the harvest or capture, display, and } \\
\text { sale of wildlife (including plants and animals). } \\
\text { IN-D3.a. Convention on International Trade in } \\
\text { Endangered Species } \\
\text { of Wild Fauna and Flora (CITES) } \\
\text { IN-D3.b. Regulations and standards for controlling } \\
\text { harvesting or capture, display, sale, of plants and } \\
\text { animals }\end{array}$} & $\begin{array}{l}\text { A.9.1. The tourism department will make sure that none } \\
\text { of the products purchased by tourist establishments } \\
\text { comes from species considered as endangered by } \\
\text { international conventions or protected by law in the } \\
\text { country where the establishment is located. }\end{array}$ \\
\hline & $\begin{array}{l}\text { A.9.2. The use of chemicals (detergents, insecticides, } \\
\text { plant protection products, etc.) should be minimized } \\
\text { and their environmental compatibility maximized. }\end{array}$ \\
\hline & $\begin{array}{l}\text { A.9.3. The tourism departments promote the use of } \\
\text { recycled paper and implement best practices, such as } \\
\text { using both sides of paper sheets, e-mails, etc., avoid } \\
\text { using chloride-based paper as far as possible. }\end{array}$ \\
\hline & $\begin{array}{l}\text { A.9.4. In order to ensure that its origin is compatible } \\
\text { with sustainability principles, all wood purchased } \\
\text { should be certified, to the extent feasible. }\end{array}$ \\
\hline & $\begin{array}{l}\text { A.9.5. Priority should be given to those suppliers/ } \\
\text { subcontractors following best practices regarding } \\
\text { sustainability, both in terms of products and processes. } \\
\text { This should be communicated to all of them. }\end{array}$ \\
\hline $\begin{array}{l}\text { A12 Safety and security } \\
\text { The destination has a system to monitor, prevent, } \\
\text { publicly report, and respond to crime, safety, and } \\
\text { health hazards. } \\
\text { IN-A12.a. On-going compulsory inspections of } \\
\text { fire, food hygiene, and electricity safety for tourism } \\
\text { properties } \\
\text { IN-A12.e. Public reporting of safety and security }\end{array}$ & $\begin{array}{l}\text { A.10.2. The destination must ensure the adoption of the } \\
\text { necessary measures to ensure visitor safety in terms } \\
\text { of fire prevention and escapes routes according to the } \\
\text { law. In case there is no legislation, the destination shall } \\
\text { prove that it is implementing sufficient measures based } \\
\text { on commonly accepted benchmarks. }\end{array}$ \\
\hline $\begin{array}{l}\text { A13 Crisis and emergency management } \\
\text { The destination has a crisis and emergency } \\
\text { response plan that is appropriate to the destination. } \\
\text { Key elements are communicated to residents, } \\
\text { visitors, and enterprises. The plan establishes } \\
\text { procedures and provides resources and training for } \\
\text { staff, visitors, and residents, and is updated on a } \\
\text { regular basis. } \\
\text { IN-A13.a. Publicly available crisis and emergency } \\
\text { response plan that considers the tourism sector } \\
\text { IN-A13.b. Financial and human capital to } \\
\text { implement the crisis and emergency response plan } \\
\text { IN-A13.c. Crisis and emergency response plan } \\
\text { developed with input from the tourism private } \\
\text { sector and includes communication procedures for } \\
\text { during and after a crisis or emergency } \\
\text { IN-A13.d. Crisis and emergency response plan } \\
\text { provides resources and training for staff, visitors, } \\
\text { and residents } \\
\text { IN-A13.e. Crisis and emergency response plan is } \\
\text { updated on a regular basis }\end{array}$ & $\begin{array}{l}\text { A.10.3. The destination must have a crisis and } \\
\text { emergency response plan for the purpose of visitor } \\
\text { protection. The plan establishes procedures and } \\
\text { provides resources and training for staff, visitors, and } \\
\text { residents, and is updated on a regular basis. }\end{array}$ \\
\hline
\end{tabular}




\section{A12 Safety and security}

The destination has a system to monitor, prevent, publicly report, and respond to crime, safety, and health hazards.

IN-A12.a. On-going compulsory inspections of fire, food hygiene, and electricity safety for tourism properties

IN-A12.b. Safety precautions such as first aid stations at beaches/tourist attraction sites

IN-A12.c. System to prevent and respond to crime

IN-A12.d. Taxi licensing system with clear pricing and an organized taxi dispatch system at points of visitor entry

IN-A12.e. Public reporting of safety and security
A.10.4. The destination must ensure the necessary hygiene and food security standards according to legal provisions, if applicable. In case there is no legislation, the destination shall prove that these requirements are ensured based on commonly accepted benchmarks.

A.10.5. The destination must ensure all necessary safety requirements in public swimming pools, if any, in terms of security of the facility, water quality and reduction of chemicals for its treatment.

A.10.6. In those facilities that use water in their operation and produce aerosols, which may be susceptible of becoming breeding grounds for the proliferation and spread of harmful pathogens, such as legionella, programmes have to be carried out for the their periodic maintenance, as well as for the control of the microbiological and physico-chemical quality of the water, so that they don't pose a risk to public health, according to the applicable legislation, if any. Such programmes will include, at least, cleaning of the facility and, if needed, its disinfection.

A.10.7. Those non-potable water supply points of the destination must be clearly identified and marked as such.

\section{C3 Visitor behavior}

The destination has published and provided guidelines for proper visitor behavior at sensitive sites. Such guidelines are designed to minimize adverse impacts on sensitive sites and strengthen positive visitor behaviors.

IN-C3.a. Cultural and environmental guidelines for visitor behaviour in sensitive sites

IN-C3.b. Code of practice for tour guides and tour operators

A.11.1. The destination must have an information service for visitors that provides them with the basic elements needed for the promotion of a respectful behaviour towards the destination in terms of environmental issues (energy saving, water saving, noise generation and other annoyances, as well as waste management), as well as behavioural guidelines giving recommendations about their preservation and sustainable use. It may be based on fact sheets, leaflets, information in telematic format or any other equivalent material having the following characteristics:

- They should be located in places with the greatest flows of tourists.

- They should be written in languages pertinent to visitors, including the local language.

- They should clearly request visitor's collaboration, explaining the reasons why such behaviour is requested and describing recommended behaviour. 


\section{C4 Cultural heritage protection}

The destination has laws governing the proper sale, trade, display, or gifting of historical and archaeological artifacts.

IN-C4.a. Laws or regulations to protect historical and archaeological artifacts including those located under water, and evidence of their enforcement

IN-C4.b. Program to protect and celebrate intangible cultural heritage (e.g., includes song, music, drama, skills and crafts)
A.11.2. Also, tourism promotions have to be developed in order to increase the visitor's knowledge of the values, customs, traditions, etc. of the local community.

A.11.3. The destination must develop mechanism to ensure the visitor's access to natural sites, landmarks, cultural resources, gastronomy, customs, etc. in order to facilitate his integration and understanding of local values, employing trained professionals that will ensure this accessibility.

B6 Tourism awareness and education

The destination provides regular programs to affected communities to enhance their understanding of the opportunities and challenges of tourism, and the importance of sustainability.

IN-B6.a. Program to raise awareness of tourism's role and potential contribution held in communities, schools, and higher education institutions

\section{A10 Visitor satisfaction}

The destination has a system to monitor and publicly report visitor satisfaction, and, if necessary, to take action to improve visitor satisfaction.

IN-A10.a. Collection and public reporting of data on visitor satisfaction

IN-A10.b. System to take action to improve visitor satisfaction based on monitoring information

A11 Sustainability standards

The destination has a system to promote sustainability standards for enterprises consistent with the GSTC Criteria. The destination makes publicly available a list of sustainability certified or verified enterprises.

IN-A11.a. Industry-supported sustainable tourism certification or environmental management system IN-A11.b. Sustainable tourism certification or environmental management system recognized by the GSTC

IN-A11.c. Monitoring of tourism business participation in tourism certification or environmental management system

IN-A11.d. Publicly available list of sustainably certified or verified enterprises
A.11.4. The destination must inform its visitors about the activities carried out in favour of the destination regarding environmental, social en economic aspects, and enabling the participation of the visitor to the extent feasible.

\section{Quality of the service}

A.12.1. Destinations should have mechanisms to monitor, assess and publicly report visitor satisfaction, and, if necessary, to take action to improve visitor satisfaction and promote the quality of tourism services at all levels.

A.12.2. The destination has a system to promote sustainability standards for enterprises consistent with the GSTC Criteria. The destination makes publicly available a list of sustainability certified or verified enterprises. 


\begin{tabular}{|c|c|}
\hline & $\begin{array}{l}\text { A.12.3. There must be behavioural and appearance } \\
\text { guidelines for the staff. These guidelines shall be } \\
\text { delivered to all employees of tourism offices and/or } \\
\text { municipal services. }\end{array}$ \\
\hline & $\begin{array}{l}\text { A.12.4. Training on tourism quality for enterprises of } \\
\text { the destination should be promoted. }\end{array}$ \\
\hline & $\begin{array}{l}\text { A.12.5. There must be guidelines for control in order to } \\
\text { ensure that services are appropriately delivered. }\end{array}$ \\
\hline & $\begin{array}{l}\text { A.12.6. Visitors should be informed about the } \\
\text { possibility of sending their suggestions and complaints } \\
\text { to the Responsible Tourism Institute, providing them } \\
\text { with the necessary information to do so. }\end{array}$ \\
\hline $\begin{array}{l}\text { A8 Access for all } \\
\text { Where appropriate, sites and facilities, including } \\
\text { those of natural and cultural importance, are } \\
\text { accessible to all, including persons with disabilities } \\
\text { and others who have specific access requirements. } \\
\text { Where such sites and facilities are not immediately } \\
\text { accessible, access is afforded through the design } \\
\text { and implementation of solutions that take into } \\
\text { account both the integrity of the site and such } \\
\text { reasonable accommodations for persons with } \\
\text { access requirements as can be achieved. } \\
\text { IN-A8.a. Policies supporting access to tourist } \\
\text { sites and facilities, including those of natural and } \\
\text { cultural importance, for individuals with disabilities } \\
\text { and others who have specific access requirements, } \\
\text { where appropriate } \\
\text { IN-A8.b. Accessibility solutions are designed to } \\
\text { take into account the integrity of the site while } \\
\text { making reasonable accommodation for people with } \\
\text { disabilities }\end{array}$ & $\begin{array}{l}\text { Accesssibility } \\
\text { A.13.1. Where appropriate, the destination must ensure } \\
\text { that sites and facilities, including those of natural and } \\
\text { cultural importance, are accessible to all, including } \\
\text { persons with disabilities and others who have specific } \\
\text { access requirements. } \\
\text { Where such sites and facilities are not immediately } \\
\text { accessible, access is afforded through the design and } \\
\text { implementation of solutions that take into account } \\
\text { both the integrity of the site and such reasonable } \\
\text { accommodations for persons with access requirements } \\
\text { as can be achieved. }\end{array}$ \\
\hline $\begin{array}{l}\text { B1 Economic monitoring } \\
\text { The direct and indirect economic contribution of } \\
\text { tourism to the destination's economy is monitored } \\
\text { and publicly reported at least annually. To the extent } \\
\text { feasible, this should include visitor expenditure, } \\
\text { revenue per available room, employment and } \\
\text { investment data. } \\
\text { IN-B1.a. Regular monitoring and reporting of } \\
\text { visitor expenditure data, revenue per available } \\
\text { room, employment and investment data } \\
\text { IN-B1.b. Regular monitoring and reporting at least } \\
\text { annually of direct and indirect contributions of } \\
\text { tourism } \\
\text { IN-B1.c. Collection and public reporting at least } \\
\text { annually of tourism-related employment data, } \\
\text { disaggregated by gender and age group }\end{array}$ & $\begin{array}{l}\text { Responsible management in the economic sphere } \\
\text { B.1.1. The direct and indirect economic contribution } \\
\text { of tourism to the destination's economy is monitored } \\
\text { and publicly reported at least annually. To the extent } \\
\text { feasible, this should include visitor expenditure, } \\
\text { revenue per available room, employment and } \\
\text { investment data. }\end{array}$ \\
\hline
\end{tabular}




\begin{tabular}{|c|c|}
\hline & $\begin{array}{l}\text { B.1.3. Development of an acting programme in } \\
\text { favour of local products and services (fairs, markets, } \\
\text { congresses, etc.). }\end{array}$ \\
\hline \multirow[t]{7}{*}{$\begin{array}{l}\text { B2 Local career opportunities } \\
\text { The destination's enterprises provide equal } \\
\text { employment, training opportunities, occupational } \\
\text { safety, and fair wages for all. } \\
\text { IN-B2.a. Legislation or policies supporting equal } \\
\text { opportunities in employment for all, including } \\
\text { women, youth, disabled people, minorities, and } \\
\text { other vulnerable populations } \\
\text { IN-B2.b. Training programs that provide equal } \\
\text { access to all, including women, youth, disabled } \\
\text { people, minorities, and other vulnerable populations } \\
\text { IN-B2.c. Legislation or policies supporting } \\
\text { occupational safety for all } \\
\text { IN-B2.d. Legislation or policies supporting fair } \\
\text { wages for all, including women, youth, disabled } \\
\text { people, minorities, and other vulnerable populations }\end{array}$} & $\begin{array}{l}\text { B.1.4. Programme for the identification of training } \\
\text { needs for employees qualified in tourism, and } \\
\text { development of actions for such training. }\end{array}$ \\
\hline & $\begin{array}{l}\text { B.1.5. Development of programmes to promote local } \\
\text { ownership and management of tourism facilities and } \\
\text { services (credits at low interest rates, incentives for } \\
\text { local investors, information and technical services, } \\
\text { etc.). }\end{array}$ \\
\hline & $\begin{array}{l}\text { B.1.6. Creating incentives for local tourism enterprises } \\
\text { (SMEs) to incorporate new technologies. }\end{array}$ \\
\hline & $\begin{array}{l}\text { Promotion of the economic and social development } \\
\text { of the community } \\
\text { B.2.1. The department responsible for tourism } \\
\text { should promote municipal sustainability projects, } \\
\text { such as Local Agenda } 21 \text {, the Biosphere Destination } \\
\text { certification, etc. }\end{array}$ \\
\hline & $\begin{array}{l}\text { B.2.3. The department responsible for tourism must } \\
\text { promote the collaboration in campaigns with social } \\
\text { purposes, such as donation of used objects, food } \\
\text { banks, etc., carried out by tourism companies at the } \\
\text { destinations. }\end{array}$ \\
\hline & $\begin{array}{l}\text { Generation of job opportunities in the tourism } \\
\text { sector and training } \\
\text { B.3.1. They must employ or promote their employees } \\
\text { regardless of their gender, religion, race, sexual } \\
\text { orientation, etc., providing fair wages for all. }\end{array}$ \\
\hline & $\begin{array}{l}\text { B.3.2. They must develop training actions for their } \\
\text { employees related to the tasks undertaken in their work } \\
\text { and to sustainability. }\end{array}$ \\
\hline
\end{tabular}




\begin{tabular}{|c|c|}
\hline & $\begin{array}{l}\text { B.3.3. They must apply some measure for the } \\
\text { reconciliation of work and family life of their } \\
\text { employees, such as granting social benefits, incentive } \\
\text { schemes, etc. }\end{array}$ \\
\hline & $\begin{array}{l}\text { B.3.4. Child labour not is allowed under any } \\
\text { circumstances. }\end{array}$ \\
\hline & $\begin{array}{l}\text { B.3.5. They must ensure the prevention of occupational } \\
\text { risks for all employees, applying the corresponding } \\
\text { legislation, if any. In case there is no legislation, the } \\
\text { Department must ensure the safety of its employees } \\
\text { based on the international provisions of ILO. }\end{array}$ \\
\hline & $\begin{array}{l}\text { B.3.6. They must promote the recruitment of disabled } \\
\text { workers. }\end{array}$ \\
\hline & $\begin{array}{l}\text { B.3.7. The body responsible for the responsible } \\
\text { tourism Management System at the destination must } \\
\text { ensure the development of actions designed to promote } \\
\text { the recruitment of local staff within the private tourism } \\
\text { sector. }\end{array}$ \\
\hline $\begin{array}{l}\text { B3 Public participation } \\
\text { The destination has a system that encourages public } \\
\text { participation in destination planning and decision } \\
\text { making on an ongoing basis. } \\
\text { IN-B3.a. System for involving public, private, and } \\
\text { community stakeholders in destination management } \\
\text { planning and decision making } \\
\text { IN-B3.b. Public meeting(s) to discuss destination } \\
\text { management issues } \\
\text { each year }\end{array}$ & $\begin{array}{l}\text { Tools for civic participation in tourism and } \\
\text { measurement of the satisfaction of the local } \\
\text { community } \\
\text { B.4.1. The destination must have a system that } \\
\text { promotes public participation in destination planning } \\
\text { and decision making. }\end{array}$ \\
\hline $\begin{array}{l}\text { B8 Support for community } \\
\text { The destination has a system to enable and } \\
\text { encourage enterprises, visitors, and the public } \\
\text { to contribute to community and sustainability } \\
\text { initiatives. } \\
\text { IN-B8.a. Programs for enterprises, visitors, and } \\
\text { the public to contribute donations to community } \\
\text { and biodiversity conservation initiatives and/or } \\
\text { infrastructure development }\end{array}$ & $\begin{array}{l}\text { B.4.2. The destination must involve tourism in the } \\
\text { social life of the community, allowing it to participate } \\
\text { and collaborate with the social events held, even } \\
\text { lending its facilities, whenever possible and their } \\
\text { characteristics allow it. }\end{array}$ \\
\hline $\begin{array}{l}\text { B4 Local community opinion } \\
\text { Local communities' aspirations, concerns, and } \\
\text { satisfaction with destination management are } \\
\text { regularly monitored, recorded and publicly reported } \\
\text { in a timely manner. } \\
\text { IN-B4.a. Regular collection, monitoring, recording, } \\
\text { and public reporting } \\
\text { of data on resident aspirations, concerns, and } \\
\text { satisfaction with } \\
\text { destination management } \\
\text { IN-B4.b. Collection, monitoring, recording, and } \\
\text { public recording of data occurs in a timely manner }\end{array}$ & $\begin{array}{l}\text { B.4.3. It must also have tools and records for the } \\
\text { assessment of aspirations, concerns, and satisfaction } \\
\text { of local communities in terms of the management } \\
\text { of the tourism activity through surveys, polls, etc. } \\
\text { This information must be publicly reported in the } \\
\text { appropriate manner. }\end{array}$ \\
\hline
\end{tabular}




\section{B5 Local access}

The destination monitors, protects, and when necessary rehabilitates or restores local community access to natural and cultural sites.

IN-B5.a. Programs to monitor, protect, and rehabilitate or restore public access by locals and domestic visitors to natural and cultural sites

IN-B5.b. Monitoring of behaviour and characteristics of local, domestic and foreign visitors to tourist sites and attractions

\section{B7 Preventing exploitation}

The destination has laws and established practices to prevent commercial, sexual, or any other form of exploitation and harassment of anyone, particularly of children, adolescents, women, and minorities. The laws and established practices are publicly communicated.

IN-B7.a. Laws and a program to prevent commercial, sexual, or any other form of exploitation, discrimination or harassment of residents or visitors

IN-B7.b. Laws and program are publicly communicated

B9 Supporting local entrepreneurs and fair trade The destination has a system that supports local and small- and medium-sized enterprises, and promotes and develops local sustainable products and fair trade principles that are based on the area's nature and culture. These may include food and beverages, crafts, performance arts, agricultural products, etc. IN-B9.a. Program to support and build capacity of local and small- and medium-sized enterprises IN-B9.b. Program encourages enterprises to purchase goods and services locally

IN-B9.c. Program to promote and develop local sustainable products based on local nature and culture

IN-B9.d. Program to include local artisans, farmers, and suppliers in the tourism value chain

\section{Population access to destination sources}

B.5.1. The destination protects local community access to natural, historical, archaeological, religious, spiritual and cultural sites, including the use of land and water resources, rights of way, transport and accommodation. When necessary, the destination will rehabilitate or restore local community access to natural and cultural sites.

Policy for the prevention of commercial, sexual or any other kind of exploitation

B.6.1. The agency responsible for the responsible tourism Management System has laws and clear and accurate policies to prevent commercial, sexual, or any other form of exploitation and harassment of anyone, particularly of children, adolescents, women, and minorities, reporting evidence of control in the mail tourism resources. The laws and established practices are publicly communicated.

Promotion of the multiplying effect and of fair and/ or local trade

B.7.1. The agency responsible for the responsible tourism Management System must ensure that measures are taken to promote responsible acquisitions, supporting local and small- and mediumsized enterprises, and promoting local sustainable products and fair trade principles that are based on the area's nature and culture. These may include food and beverages, crafts, performance arts, agricultural products, etc. These measures must be met by the managing body/bodies and/or any other agency involved in the System in any way. They must also be actively promoted within the private sector.

B.7.2. Visitors must be provided with information on sites, museums, restaurants, shops and services in order to promote their visits and consumption, allowing for a multiplying effect beyond the most usual and crowded tourism resources.

A6 Inventory of tourism assets and attractions The destination has an up-to-date, publicly available inventory and assessment of its tourism assets and attractions, including natural and cultural sites. IN-A6.a. Current inventory and classification of tourism assets and attractions including natural and cultural sites
Responsible management in the socio-cultural sphere

C.1.1. The destination has an up-to-date, publicly available inventory, a Plan of action and assessment of its tourism assets and attractions, including natural and cultural sites. 


\section{C6 Intellectual property}

The destination has a system to contribute to the protection and preservation of intellectual property rights of communities and individuals.

IN-C6.a. Laws, regulations or programs to protect intellectual property rights of local individuals and communities
C.1.2. The destination has a system to contribute to the protection and preservation of intellectual property rights of communities and individuals.

C.1.3. Creation and development of initiatives with the participation of citizens and interested parties in the decision-making process in terms of tourism.

B6 Tourism awareness and education

The destination provides regular programs to affected communities to enhance their understanding of the opportunities and challenges of tourism, and the importance of sustainability. IN-B6.a. Program to raise awareness of tourism's role and potential contribution held in communities, schools, and higher education institutions
C.1.4. Elaboration of training, information and awareness campaigns on sustainable tourism, both for entrepreneurs and citizens.

C.1.5. The destination provides regular programs to affected communities to enhance their understanding of the opportunities and challenges of tourism, and the importance of sustainability.

C.1.6. Development of an acting programme in favour of tangible and intangible cultural heritage: festivals, folklore, etc.

\section{C4 Cultural heritage protection}

The destination has laws governing the proper sale, trade, display, or gifting of historical and archaeological artifacts.

IN-C4.a. Laws or regulations to protect historical and archaeological artifacts including those located under water, and evidence of their enforcement IN-C4.b. Program to protect and celebrate intangible cultural heritage (e.g., includes song, music, drama, skills and crafts)
C.1.7. The destination has laws governing the proper sale, trade, display, or gifting of historical and archaeological artifacts. It must also develop specific actions for the protection and preservation of crafts and local arts. Besides, they won't be allowed to sale, trade or display historical and archaeological artifacts unless legally permissible.

\section{C1 Attraction protection}

The destination has a policy and system to evaluate, rehabilitate, and conserve natural and cultural sites, including built heritage (historic and archaeological) and rural and urban scenic views.

IN-C1.a. Management system to protect natural and cultural sites, including build heritage and rural and urban scenic views

IN-C1.b. Management system to monitor, measure, and mitigate tourism impacts on sites and attractions
C.1.8. Definition of building restrictions for tourism facilities in order to ensure the respect for local architecture.

C.1.9. The destination has a policy and system to evaluate, rehabilitate, and conserve natural and cultural sites, including built heritage (historic and archaeological) and rural and urban scenic views. 
IN-B2.b. Training programs that provide equal access to all, including women, youth, disabled people, minorities, and other vulnerable populations

\section{B5 Local access}

The destination monitors, protects, and when necessary rehabilitates or restores local community access to natural and cultural sites.

IN-B5.a. Programs to monitor, protect, and rehabilitate or restore public access by locals and domestic visitors to natural and cultural sites

IN-B5.b. Monitoring of behaviour and characteristics of local, domestic and foreign visitors to tourist sites and attractions
C.1.10. Creation of mechanisms to maximize social cohesion and minimize conflict, such as training and employment programmes for groups in danger of social exclusion.

C.1.11. Development of mechanisms to ensure access to all facilities and attractions generated by tourism for the residents.
IN-B2.a. Legislation or policies supporting equal opportunities in employment for all, including women, youth, disabled people, minorities, and other vulnerable populations

IN-B2.b. Training programs that provide equal access to all, including women, youth, disabled people, minorities, and other vulnerable populations IN-B2.d. Legislation or policies supporting fair wages for all, including women, youth, disabled people, minorities, and other vulnerable populations

\section{$\mathrm{C} 2$ Visitor management}

IN-C2.a. Administrative mechanism responsible for implementing visitor management plans and operations
C.1.12. Development of mechanisms to support developing countries, to the extent feasible.

C.1.13. Development of measures to minimize gender, race, religious and sexual discrimination within the tourism sector.
Plan for the management of visitors and the capacity of the destination

C.2.1. The destination must establish a visitor management system that assesses the distribution of the tourism activity in districts, areas or territorial resources, including measures to preserve, protect, and enhance natural and cultural assets, in order to avoid overcrowding and always taking into account the carrying capacity of the destination.

C.2.2. There should also be measures to promote a more equitable distribution of benefits and burdens generated by tourism.

\section{D1 Environmental risks}

The destination has identified environmental risks and has a system in place to address them. D2 Protection of sensitive environments The destination has a system to monitor the environmental impact of tourism, conserve habitats, species, and ecosystems, and prevent the introduction of invasive species.

\section{C.2.3. The destination must establish indicators for the} carrying capacity of tourism in order to prevent tourism over-exploitation and deterioration of the environment. Public and private institutions must take action focused on the integrated planning of tourism as a contribution to sustainable development. Environmentally and culturally vulnerable areas must be a priority when planning financial aid and technical cooperation to sustainable tourism development.

Promotion of knowledge among visitors

C.4.1. The destination must promote local gastronomy in its offer. 


\begin{tabular}{|c|c|}
\hline & $\begin{array}{l}\text { C. } 4.2 \text {. The destination must promote sustainability } \\
\text { certification of restaurants. }\end{array}$ \\
\hline & $\begin{array}{l}\text { C. } 4.3 \text {. The destination must offer activities related to } \\
\text { its cultural resources. }\end{array}$ \\
\hline & $\begin{array}{l}\text { C.4.4. The destination must provide visitors with } \\
\text { information about the main cultural resources in the } \\
\text { area, providing information about opening hours, } \\
\text { natural surroundings, appropriate behaviour, etc. }\end{array}$ \\
\hline $\begin{array}{l}\text { C5 Site interpretation } \\
\text { Accurate interpretive information is provided } \\
\text { at natural and cultural sites. The information is } \\
\text { culturally appropriate, developed with community } \\
\text { collaboration, and communicated in languages } \\
\text { pertinent to visitors. } \\
\text { IN-C5.a. Interpretive information available to } \\
\text { visitors in tourist offices } \\
\text { and at natural and cultural sites } \\
\text { IN-C5.b. Interpretive information is culturally } \\
\text { appropriate } \\
\text { IN-C5.c. Interpretive information is developed with } \\
\text { community collaboration } \\
\text { IN-C5.d. Interpretive information is available in } \\
\text { languages pertinent to visitors } \\
\text { IN-C5.e. Tour guide training in the use of } \\
\text { interpretive information }\end{array}$ & $\begin{array}{l}\text { C.4.5. The destination provides accurate interpretive } \\
\text { information at natural and cultural sites. The } \\
\text { information is culturally appropriate, developed with } \\
\text { community collaboration, and communicated in } \\
\text { languages pertinent to visitors. }\end{array}$ \\
\hline \multicolumn{2}{|l|}{$\begin{array}{l}\text { C6 Intellectual property } \\
\text { The destination has a system to contribute to the } \\
\text { protection and preservation of intellectual property } \\
\text { rights of communities and individuals. } \\
\text { IN-C6.a. Laws, regulations or programs to protect } \\
\text { intellectual property rights of local individuals and } \\
\text { communities }\end{array}$} \\
\hline $\begin{array}{l}\text { C4 Cultural heritage protection } \\
\text { The destination has laws governing the proper } \\
\text { sale, trade, display, or gifting of historical and } \\
\text { archaeological artifacts. } \\
\text { IN-C4.a. Laws or regulations to protect historical } \\
\text { and archaeological artifacts including those located } \\
\text { under water, and evidence of their enforcement } \\
\text { IN-C4.b. Program to protect and celebrate } \\
\text { intangible cultural heritage (e.g., includes song, } \\
\text { music, drama, skills and crafts) }\end{array}$ & $\begin{array}{l}\text { Tools to support the development and maintenance } \\
\text { of the culture of the destination by tourists } \\
\text { C.5.1. The destination must establish mechanisms } \\
\text { for interested visitors to actively collaborate with } \\
\text { the destination in its preservation, conservation and } \\
\text { cultural promotion. }\end{array}$ \\
\hline $\begin{array}{l}\text { C3 Visitor behavior } \\
\text { The destination has published and provided } \\
\text { guidelines for proper visitor behavior at sensitive } \\
\text { sites. Such guidelines are designed to minimize } \\
\text { adverse impacts on sensitive sites and strengthen } \\
\text { positive visitor behaviors. } \\
\text { IN-C3.a. Cultural and environmental guidelines for } \\
\text { visitor behaviour in sensitive sites } \\
\text { IN-C3.b. Code of practice for tour guides and tour } \\
\text { operators }\end{array}$ & $\begin{array}{l}\text { Responsible behaviour } \\
\text { C. } 6.1 \text { The destination has published and provided } \\
\text { guidelines for proper visitor behaviour at sensitive } \\
\text { sites. Such guidelines are designed to minimize } \\
\text { adverse impacts on sensitive sites and strengthen } \\
\text { positive visitor behaviours. }\end{array}$ \\
\hline
\end{tabular}




\section{D1 Environmental risks}

The destination has identified environmental risks and has a system in place to address them.

IN-D1.a. Sustainability assessment of the destination within the last five years, identifying environmental risks

IN-D1.b. System in place to address identified risks

\section{D2 Protection of sensitive environments}

The destination has a system to monitor the environmental impact of tourism, conserve habitats, species, and ecosystems, and prevent the introduction of invasive species.

IN-D2.a. Maintained and updated inventory of sensitive and threatened wildlife and habitats

IN-D2.b. Management system to monitor impacts and to protect ecosystems,

\section{Landscape protection and environmental impact} assessment studies

D.1.1. The destination must carry out an environmental impact assessment study in terms of land use. This study must include a system for the assessment of the impact of tourism and the management of the impacts of intensive tourism on landscapes and ecosystems, including vulnerable or endangered wildlife habitats. It must also include a visitor management system for attraction sites that includes measures to preserve, protect, and enhance natural and cultural assets.

D.1.2. The destination has a system to monitor the environmental impact of tourism, conserve habitats, species, and ecosystems, and prevent the introduction of invasive species.

D.1.3. To the extent feasible, the destination must request or encourage tourism enterprises to have an environmental management plan that includes measures to control vegetation, landfills, to avoid the introduction of invasive species and implement other control measures to avoid pollution.

D.1.4. The destination must check that facilities and infrastructures don't have an impact on the landscape, developing mechanisms to minimize the impact of buildings and infrastructures on the landscape.

D.1.5. Outdoor signage should not have an impact either.

D.1.6. Gardens must prioritize native species in order not to cause a severe alteration of the natural landscape.

\section{D12 Low-impact transportation}

The destination has a system to increase the use of low-impact transportation, including public transportation and active transportation (e.g., walking and cycling).

IN-D12.a. Program to increase the use of lowimpact transportation

IN-D12.b. Program to make sites of visitor interest more accessible to active transportation (e.g., walking and cycling)

\section{Sustainable transport}

D.2.1 The destination has a system to increase the use of low-impact transportation, including public transportation and active transportation (e.g., walking and cycling).

D.2.2. Promotion of bike lanes (where possible).

D.2.3. Development of mechanisms in order to ensure that tourists have access to a quality public transport system. 


\begin{tabular}{|c|c|}
\hline & $\begin{array}{l}\text { Natural resources } \\
\text { D.3.1. The destination has identified environmental } \\
\text { risks and has a system in place to address them. }\end{array}$ \\
\hline \multirow{2}{*}{$\begin{array}{l}\text { A6 Inventory of tourism assets and attractions } \\
\text { The destination has an up-to-date, publicly available } \\
\text { inventory and assessment of its tourism assets and } \\
\text { attractions, including natural and cultural sites. } \\
\text { IN-A6.a. Current inventory and classification of } \\
\text { tourism assets and attractions including natural and } \\
\text { cultural sites }\end{array}$} & $\begin{array}{l}\text { D.3.2. The destination has an up-to-date, publicly } \\
\text { available inventory of its natural resources (fauna, } \\
\text { flora, etc.) and assessment of its tourism assets and } \\
\text { attractions, including natural and sensitive sites. These } \\
\text { must be publicly available. }\end{array}$ \\
\hline & $\begin{array}{l}\text { D.3.3. Development of measures to preserve these } \\
\text { sites and resources. }\end{array}$ \\
\hline $\begin{array}{l}\text { D3 Wildlife protection } \\
\text { The destination has a system to ensure compliance } \\
\text { with local, national, and international laws and } \\
\text { standards for the harvest or capture, display, and } \\
\text { sale of wildlife (including plants and animals). } \\
\text { IN-D3.a. Convention on International Trade in } \\
\text { Endangered Species } \\
\text { of Wild Fauna and Flora (CITES) } \\
\text { IN-D3.b. Regulations and standards for controlling } \\
\text { harvesting or capture, display, sale, of plants and } \\
\text { animals }\end{array}$ & $\begin{array}{l}\text { Wildlife protection } \\
\text { D.4.1.The destination has a system to ensure } \\
\text { compliance with local, national, and international laws } \\
\text { and standards for the harvest or capture, display, and } \\
\text { sale of wildlife (including plants and animals). }\end{array}$ \\
\hline \multirow{4}{*}{$\begin{array}{l}\text { D5 Energy conservation } \\
\text { The destination has a system to encourage } \\
\text { enterprises to measure, monitor, reduce, and } \\
\text { publicly report energy consumption, and reduce } \\
\text { reliance on fossil fuels. } \\
\text { IN-D5.a. Program to promote energy conservation } \\
\text { and measure, monitor, reduce, and publicly report } \\
\text { energy consumption } \\
\text { IN-D5.b. Policies and incentives to reduce reliance } \\
\text { on fossil fuels, } \\
\text { improve energy efficiency, and encourage the } \\
\text { adoption and use of renewable energy technologies }\end{array}$} & $\begin{array}{l}\text { Energy management and control } \\
\text { D.5.1. The destination has a system to encourage } \\
\text { enterprises to measure, reduce, and publicly report } \\
\text { energy consumption, and reduce reliance on fossil } \\
\text { fuels. }\end{array}$ \\
\hline & $\begin{array}{l}\text { D.5.2. It must also implement general saving practices } \\
\text { such as turning lights en devices off after use, avoiding } \\
\text { the unnecessary use of air conditioning or heating, } \\
\text { disconnecting devices that are not being used, etc. } \\
\text { There should be written guidelines. }\end{array}$ \\
\hline & $\begin{array}{l}\text { D.5.3. Best technologies available should be } \\
\text { promoted within the tourism sector to reduce energy } \\
\text { consumption: Clean energies, bioclimatic techniques, } \\
\text { use of waste heat, etc. }\end{array}$ \\
\hline & $\begin{array}{l}\text { D.5.4. The destination must ensure the purchase of } \\
\text { equipment with the highest energy efficiency, including } \\
\text { luminaires, boilers, white goods, cameras, etc. }\end{array}$ \\
\hline
\end{tabular}




\begin{tabular}{|c|c|}
\hline & $\begin{array}{l}\text { D.5.5. Energy losses of all equipment must be } \\
\text { minimized through the use of appropriate insulation } \\
\text { (pipes, batteries, watertight joints, etc.), cleaning plans } \\
\text { (heat exchangers, evaporators, etc.), separation of cold } \\
\text { and warm areas, maintenance plans. }\end{array}$ \\
\hline & $\begin{array}{l}\text { D.5.6. Awareness plans about energy saving must be } \\
\text { developed for residents and visitors. }\end{array}$ \\
\hline & $\begin{array}{l}\text { D.5.7. Renewable energy programmes must be } \\
\text { promoted. }\end{array}$ \\
\hline \multirow[t]{4}{*}{$\begin{array}{l}\text { D6 Water Management } \\
\text { The destination has a system to encourage } \\
\text { enterprises to measure, monitor, reduce, and } \\
\text { publicly report water usage. } \\
\text { IN-D6.a. Program to assist enterprises to measure, } \\
\text { monitor, reduce, and publicly report water usage }\end{array}$} & $\begin{array}{l}\text { Water Management And Control } \\
\text { D.6.1. The destination has a system to monitor its water } \\
\text { resources and develops water saving programmes at a } \\
\text { public and private level to encourage enterprises to } \\
\text { measure, monitor, reduce, and publicly report water } \\
\text { usage. Tourism facilities must implement general } \\
\text { saving practices, such as avoiding leaving taps open, } \\
\text { repairing leaks, etc. }\end{array}$ \\
\hline & $\begin{array}{l}\text { D.6.2. There must be documented guidelines to ensure } \\
\text { the maximal water saving. }\end{array}$ \\
\hline & $\begin{array}{l}\text { D.6.3. Awareness plans about water saving must be } \\
\text { developed for residents and visitors. }\end{array}$ \\
\hline & $\begin{array}{l}\text { D.6.4. Mechanisms are developed to ensure an } \\
\text { adequate waste management. }\end{array}$ \\
\hline $\begin{array}{l}\text { D8 Water quality } \\
\text { The destination has a system to monitor drinking and } \\
\text { recreational water quality using quality standards. } \\
\text { The monitoring results are publicly available, and } \\
\text { the destination has a system to respond in a timely } \\
\text { manner to water quality issues. } \\
\text { IN-D8.a. Management system to monitor and } \\
\text { publicly report on drinking and recreational water } \\
\text { quality } \\
\text { IN-D8.b. Monitoring results are publicly available } \\
\text { IN-D8.c. System to respond in a timely manner to } \\
\text { water quality issues }\end{array}$ & $\begin{array}{l}\text { D.6.5. The destination has a system to monitor drinking } \\
\text { and recreational water quality using quality standards. } \\
\text { The monitoring results are publicly available, and the } \\
\text { destination has a system to respond in a timely manner } \\
\text { to water quality issues. }\end{array}$ \\
\hline $\begin{array}{l}\text { D.9. The destination has clear and enforced } \\
\text { guidelines in place for the siting, maintenance } \\
\text { and testing of discharge from septic tanks and } \\
\text { wastewater treatment systems, and ensures wastes } \\
\text { are properly treated and reused or released safely } \\
\text { with minimal adverse effects to the local population } \\
\text { and the environment. } \\
\text { IN-D9.a. Regulations for the siting, maintenance, } \\
\text { and testing of discharge from septic tanks and } \\
\text { wastewater treatment systems, and evidence of } \\
\text { their enforcement } \\
\text { IN-D9.b. Regulations to ensure the size and type } \\
\text { of waste water } \\
\text { treatment is adequate for the location, and evidence } \\
\text { of their enforcement } \\
\text { IN-D9.c. Program to assist enterprises to effectively } \\
\text { treat and reuse }\end{array}$ & $\begin{array}{l}\text { D.6.6. The destination has clear and enforced guidelines } \\
\text { in place for the siting, maintenance and testing of } \\
\text { discharge from septic tanks and wastewater treatment } \\
\text { systems, and ensures wastes are properly treated and } \\
\text { reused or released safely with minimal adverse effects } \\
\text { to the local population and the environment. }\end{array}$ \\
\hline
\end{tabular}




\begin{tabular}{|c|c|}
\hline & $\begin{array}{l}\text { D.6.7. The use of purified water for irrigation must be } \\
\text { prioritized. In those cases when the reuse of water is } \\
\text { not feasible, the destination will implement measures } \\
\text { that allow an efficient irrigation, adapting to the water } \\
\text { conditions of the area, such as drip irrigation, sand, } \\
\text { retention granules, appropriate schedules, etc. }\end{array}$ \\
\hline $\begin{array}{l}\text { D7 Water security } \\
\text { The destination has a system to monitor its water } \\
\text { resources to ensure that use by enterprises is } \\
\text { compatible with the water requirements of the } \\
\text { destination community. } \\
\text { IN-D7.a. Management system to ensure that water } \\
\text { use by enterprises and water requirements of the } \\
\text { destination community are balanced and compatible }\end{array}$ & $\begin{array}{l}\text { D.6.8. The destination has a system to monitor its } \\
\text { water resources to ensure that use by enterprises } \\
\text { is compatible with the water requirements of the } \\
\text { destination community. }\end{array}$ \\
\hline \multirow{3}{*}{$\begin{array}{l}\text { D4 Greenhouse gas emissions } \\
\text { The destination has a system to encourage } \\
\text { enterprises to measure, monitor, minimize, publicly } \\
\text { report, and mitigate their greenhouse gas } \\
\text { IN-D4.a. Program to assist enterprises to measure, } \\
\text { monitor, minimize, and publicly report greenhouse } \\
\text { gas emissions } \\
\text { IN-D4.b. System to assist enterprises to mitigate } \\
\text { greenhouse gas }\end{array}$} & $\begin{array}{l}\text { Greenhouse Gas Emission } \\
\text { D.7.1. The destination has a system to encourage } \\
\text { enterprises to measure, monitor, minimize, publicly } \\
\text { report, and mitigate their greenhouse gas emissions } \\
\text { from all aspects of their operation (including emissions } \\
\text { from service providers). }\end{array}$ \\
\hline & $\begin{array}{l}\text { D.7.2. The destination must ensure a healthy air } \\
\text { quality, free of pollutants. }\end{array}$ \\
\hline & $\begin{array}{l}\text { D.7.3. The destination must carry out studies on } \\
\text { greenhouse gas emission in tourist areas and establish } \\
\text { goals to their minimization. }\end{array}$ \\
\hline \multirow{5}{*}{$\begin{array}{l}\text { D11 Light and noise pollution } \\
\text { The destination has guidelines and regulations to } \\
\text { minimize light and noise pollution. The destination } \\
\text { encourages enterprises to follow these guidelines } \\
\text { and regulations. } \\
\text { IN-D11.a. Guidelines and regulations to minimize } \\
\text { noise and light pollution } \\
\text { IN-D11.b. Program to encourage enterprises to } \\
\text { follow guidelines and regulations to minimize noise } \\
\text { and light pollution }\end{array}$} & $\begin{array}{l}\text { Light And Noise Pollution } \\
\text { D.8.1. The destination has guidelines and regulations } \\
\text { to minimize light and noise pollution. The destination } \\
\text { encourages enterprises to follow these guidelines and } \\
\text { regulations. }\end{array}$ \\
\hline & $\begin{array}{l}\text { D.8.2. The destination must elaborate a noise map and } \\
\text { develop mechanisms to its minimization. }\end{array}$ \\
\hline & $\begin{array}{l}\text { Waste management and control } \\
\text { D.9.1. The destination must count on a selective } \\
\text { collection system for urban waste. }\end{array}$ \\
\hline & $\begin{array}{l}\text { D.9.2. There must be control mechanisms for landfill } \\
\text { management. }\end{array}$ \\
\hline & $\begin{array}{l}\text { D.9.3. The destination must develop the creation of } \\
\text { recycling sites with accurate information for visitors. }\end{array}$ \\
\hline
\end{tabular}




\begin{tabular}{|c|c|}
\hline & $\begin{array}{l}\text { D.9.4. Mechanisms should be developed to ensure an } \\
\text { adequate management of hazardous waste. }\end{array}$ \\
\hline \multirow[t]{4}{*}{$\begin{array}{l}\text { D10 Solid waste reduction } \\
\text { The destination has a system to encourage } \\
\text { enterprises to reduce, reuse, and recycle solid } \\
\text { waste. Any residual solid waste that is not reused } \\
\text { or recycled is disposed of safely and sustainably. } \\
\text { IN-D10.a. Waste collection system that maintains } \\
\text { public records on the amount of waste generated } \\
\text { IN-D10.b. Solid waste management plan that } \\
\text { is implemented, and has quantitative goals to } \\
\text { minimize, and ensure safe sustainable disposal of } \\
\text { waste that is not reused or recycled } \\
\text { IN-D10.c. Program to assist enterprises to reduce, } \\
\text { reuse, and recycle waste } \\
\text { IN-D10.d. Program to reduce the use of bottled } \\
\text { water by enterprises and visitors }\end{array}$} & $\begin{array}{l}\text { D.9.5. The destination has a system to encourage } \\
\text { enterprises to reduce, reuse, and recycle solid waste. } \\
\text { Any residual solid waste that is not reused or recycled } \\
\text { is disposed of safely and sustainably. It must also } \\
\text { implement general practices to minimize waste } \\
\text { generation and instruction about adequate internal } \\
\text { waste management. }\end{array}$ \\
\hline & $\begin{array}{l}\text { D.9.6. There must be documented guidelines in this } \\
\text { respect. }\end{array}$ \\
\hline & $\begin{array}{l}\text { D.9.7. Informative and awareness plans about water } \\
\text { saving must be developed for residents and visitors. }\end{array}$ \\
\hline & $\begin{array}{l}\text { D.9.8. The destination must promote the consumption } \\
\text { of products with returnable packages. }\end{array}$ \\
\hline
\end{tabular}

